\title{
Liquefaction Features Produced by the 2010-2011 Canterbury Earthquake Sequence in Southwest Christchurch, New Zealand, and Preliminary Assessment of Paleoliquefaction Features
}

by P. Villamor, P. Almond, M. P. Tuttle, M. Giona-Bucci, R. M. Langridge, K. Clark, W. Ries, S. H. Bastin, A. Eger, M. Vandergoes, M. C. Quigley, P. Barker, F. Martin, and J. Howarth

\begin{abstract}
Liquefaction features and the geologic environment in which they formed were carefully studied at two sites near Lincoln in southwest Christchurch. We undertook geomorphic mapping, excavated trenches, and obtained hand cores in areas with surficial evidence for liquefaction and areas where no surficial evidence for liquefaction was present at two sites (Hardwick and Marchand). The liquefaction features identified include (1) sand blows (singular and aligned along linear fissures), (2) blisters or injections of subhorizontal dikes into the topsoil, (3) dikes related to the blows and blisters, and (4) a collapse structure. The spatial distribution of these surface liquefaction features correlates strongly with the ridges of scroll bars in meander settings. In addition, we discovered paleoliquefaction features, including several dikes and a sand blow, in excavations at the sites of modern liquefaction. The paleoliquefaction event at the Hardwick site is dated at A.D. 908-1336, and the one at the Marchand site is dated at A.D. 1017-1840 (95\% confidence intervals of probability density functions obtained by Bayesian analysis). If both events are the same, given proximity of the sites, the time of the event is A.D. 1019-1337. If they are not, the one at the Marchand site could have been much younger. Taking into account a preliminary liquefaction-triggering threshold of equivalent peak ground acceleration for an $M_{\mathrm{w}} 7.5$ event $\left(\mathrm{PGA}_{7.5}\right)$ of $0.07 \mathrm{~g}$, existing magnitude-bounded relations for paleoliquefaction, and the timing of the paleoearthquakes and the potential $\mathrm{PGA}_{7.5}$ estimated for regional faults, we propose that the Porters Pass fault, Alpine fault, or the subduction zone faults are the most likely sources that could have triggered liquefaction at the study sites. There are other nearby regional faults that may have been the source, but there is no paleoseismic data with which to make the temporal link.
\end{abstract}

Online Material: Figures showing areas of liquefaction, trench logs, information on dike and sand-blow parameters, dike azimuths, core logs, radiocarbon samples, and $\mathrm{OxCal}$ analysis, and tables detailing units exposed in the trenches and stereonets.

\section{Introduction}

In the South Island of New Zealand, a sequence of earthquakes during 2010-2011, starting with the 4 September 2010 $M_{\mathrm{w}} 7.1$ Darfield earthquake and including the most damaging 22 February $2011 M_{\mathrm{w}} 6.2$ Christchurch earthquake (Fig. 1; Bannister and Gledhill, 2012; Kaiser et al., 2012), produced extensive liquefaction in Christchurch City and the surrounding area (Cubrinovski and Green, 2010; Cubrinovski et al., 2011; Ward et al., 2011; Brackley, 2012; Kaiser et al., 2012; Reid et al., 2012; Bastin et al., 2013, 2015; Quigley et al., 2013; Townsend et al., 2016). Prior to 2010, moderate historical earth- quakes had induced liquefaction in the Canterbury region (e.g., the $1901 M_{\mathrm{w}} 6.8$ Cheviot earthquake; Berrill et al., 1994), and liquefaction susceptibility maps of Christchurch have been available for decades (e.g., Elder et al., 1991, and others; for details, see Brackley, 2012). However, the extent of liquefaction $\left(1600 \mathrm{~km}^{2}\right.$ for the Darfield event; Townsend et al., 2016) and consequent financial loss ( \$US15 billion; Berryman, 2012) were unprecedented in New Zealand's historical records.

Extensive liquefaction during the 2010-2011 earthquake sequence provides a unique opportunity to study many aspects 

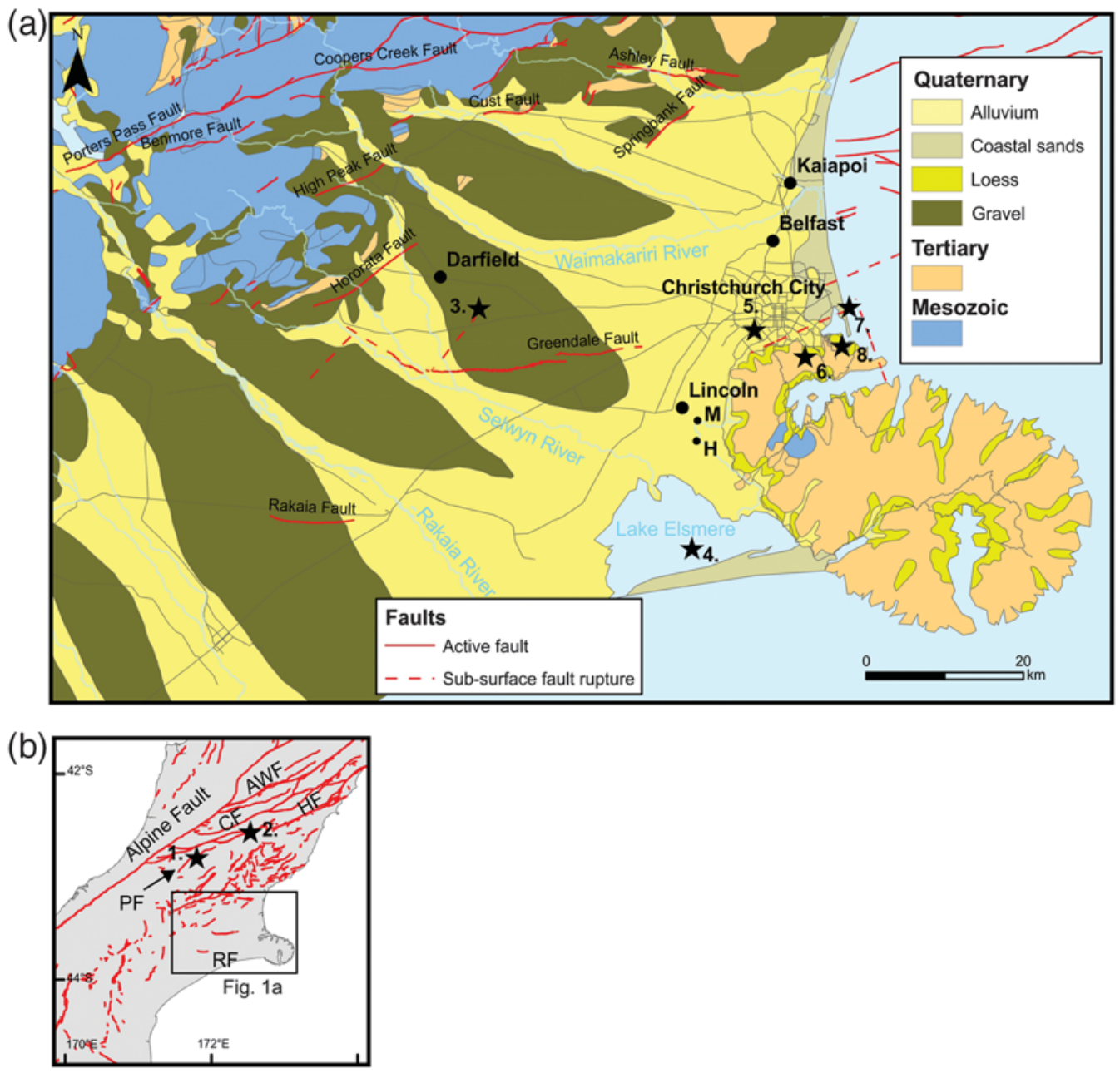

Figure 1. (a) General geology and active faults of the Canterbury region. Black stars are epicenters of historic earthquakes: (1) 1929 Arthur's Pass $\left(M_{\mathrm{w}} 7.1\right),(2) 1888$ Amuri $\left(M_{\mathrm{w}} 7.1\right)$, (3) 2010 Darfield $\left(M_{\mathrm{w}} 7.1\right)$, (4) 1870 Lake Ellesmere $\left(M_{\mathrm{w}} 5.8\right)$, (5) 1869 Christchurch $\left(M_{\mathrm{w}} 4.9\right)$, (6) February 2011 Christchurch $\left(M_{\mathrm{w}} 6.2\right)$, (7) December $2011\left(M_{\mathrm{w}}\right.$ 5.9), and (8) June $2011\left(M_{\mathrm{w}} 6.0\right)$. Small black dots are our study sites (M, Marchand site; H, Hardwick site). (b) Active faults of the central part of the South Island (Forsyth et al., 2008; Barnes et al., 2011; see Data and Resources): HF, Hope fault; CF, Clarence fault; AWF, Awatere fault; PF, Poulter fault; and RF, Rakaia fault.

of liquefaction. For example, aerial photography and light detection and ranging (lidar) surveys acquired immediately after the two largest events in the sequence, the Darfield and Christchurch earthquakes, were used to produce regional-scale maps that precisely record the locations, types, and extent of surficial liquefaction features in association with each event (Townsend et al., 2016). Also, observations of recurrent liquefaction during the sequence, following both the larger earthquakes and other moderate events have been considered, in combination with measurements of ground motion by a dense seismograph network, to assess the threshold of shaking required to induce liquefaction at a site of highly susceptible sediment (Quigley et al., 2013). Groundwater characteristics recorded during the events were successfully used to assess the influence of the liquefaction process on changes in artesian pressure in confined aquifers (Cox et al., 2012).

Paleoseismological trenching studies have contributed to an understanding of the occurrence and preservation of liquefaction features in the geologic record (Almond et al.,
2012; Bastin et al., 2013, 2015, 2016; Quigley et al., 2013; Villamor et al., 2014). A few pre-2010 liquefaction features have been found in excavations of 2010-2011 sand blows in Christchurch City. Some of the pre-2010 features tentatively have been attributed to a local historic earthquake in 1869 or, alternatively, to either the 1717 Alpine or Porters Pass earthquakes (Bastin et al., 2015).

This article considers liquefaction from the Canterbury earthquake sequence close to Lincoln township, $16 \mathrm{~km}$ to the southwest of Christchurch City. The study area lies on a late Holocene, low-lying floodplain-delta complex formed by old distributary channels of the Waimakairiri River, which now flows to the Pacific Ocean north of Christchurch (Fig. 1). The water table in the area is shallow, varying from 1.5 to $2 \mathrm{~m}$ below the surface during the dry season. We have chosen two study sites southwest of Lincoln for the following reasons.

1. Liquefaction occurred here during both the Darfield (4 September 2010) and Christchurch (22 February 2011) 
Table 1

Estimated PGA 7.5 at Hardwick and Marchand Sites from Rupture of Known Active Faults and Historic Earthquakes from GMPEs

\begin{tabular}{|c|c|c|c|c|c|c|c|}
\hline Seismic Source & Type* & $M_{\mathrm{w}}$ Mean* & Distance $^{\dagger}$ & $\begin{array}{l}\text { Recorded } \\
\text { PGA }^{\ddagger}\end{array}$ & $\begin{array}{c}\mathrm{PGA}_{7.5} \\
\text { McVerry/Bradley }\end{array}$ & $\begin{array}{c}\text { Probability (\%) } \\
\text { Maurer" }\end{array}$ & $\begin{array}{l}\text { Historic } \\
\text { Liquefaction } \\
\text { at Study Site }\end{array}$ \\
\hline Subduction zone (full rupture) & $\operatorname{Rv}$ & 9.0 & 170 & & 0.086 & & \\
\hline Subduction zone (southern segment) & Rv & $8.1-8.4$ & 170 & & $0.036-0.053$ & & \\
\hline Alpine fault & Ss & 8.1 & 135 & & $0.077 / 0.080$ & 31 & \\
\hline Hope-Conway fault & Ss & 7.4 & 120 & & $0.048 / 0.043$ & $<7$ & \\
\hline Kelly fault & Ss & 7.3 & 120 & & $0.043 / 0.038$ & $<7$ & \\
\hline Hope-Hope River fault (1888 Amuri EQ) & Ss & 7.1 & 112 & & $0.040 / 0.033$ & $<7$ & No \\
\hline Hope-Hurunui fault & Ss & 7 & 107 & & $0.038 / 0.031$ & $<7$ & \\
\hline Poulter fault & Ss & 7.1 & 109 & & $0.041 / 0.034$ & $<7$ & \\
\hline Porters Pass fault & $\mathrm{Sr}$ & 7.5 & 55 & & $0.133 / 0.121$ & 50 & \\
\hline Springfield fault & $\mathrm{Rv}$ & 7 & 58 & & $0.092 / 0.069$ & 16 & \\
\hline Ashely fault & $\mathrm{Rv}$ & 7.2 & 45 & & $0.137 / 0.018$ & 50 & \\
\hline Hororata fault & $\operatorname{Rv}$ & 7.2 & 38 & & $0.155 / 0.123$ & $50-69$ & \\
\hline Springbank fault & $\mathrm{Rv}$ & 7 & 38 & & $0.134 / 0.104$ & 50 & \\
\hline Rakaia fault & $\mathrm{Sr}$ & 7.1 & 24 & & $0.174 / 0.168$ & $69-84$ & \\
\hline Greendale, 4 September 2010 & $\mathrm{Sr}$ & 7.1 & 15 & 0.423 & 0.381 & 93 & Yes \\
\hline 1869 Christchurch earthquake & $\mathrm{Sr}$ & 4.9 & 15 & & $0.048 / 0.021$ & $<7$ & No \\
\hline 1870 Lake Elsmere earthquake & $\mathrm{Sr}$ & 5.8 & 15 & & $0.095 / 0.075$ & 50 & No \\
\hline Christchurch fault, 22 February 2011 & Rv & 6.2 & 15 & 0.118 & 0.073 & 50 & Yes \\
\hline 13 June 2011 & $\mathrm{Sr}$ & 6 & 24 & 0.071 & 0.040 & 16 & Yes \\
\hline
\end{tabular}

*From Stirling et al. (2012) for fault sources and Downes and Yetton (2012) for historic earthquakes. Ss, strike slip; Sr, strike-slip reverse; Rv, reverse. ${ }^{\dagger}$ Distance from closest point of fault source to site or epicentral distance to site (for 1869 Christchurch and 1870 Elsmere earthquakes).

${ }^{\ddagger}$ Recorded peak ground acceleration (PGA) is the geometric mean of the two horizontal components at LINC seismic station (3 km away from the study site). ${ }^{\S} \mathrm{PGA}_{7.5}$ is either the conversion of recorded PGA (for 4 September, 11 February, and 13 June events) to magnitude weighted PGA (Youd et al., 2001) or the estimated $\mathrm{PGA}_{7.5}$ value from rupture of fault sources using two ground-motion prediction equations (GMPEs): (median value) from McVerry et al. (2006; for soil type D) and Bradley (2013; for $V_{S 30}=200 \mathrm{~m} / \mathrm{s}$ and depth to $1 \mathrm{~km} / \mathrm{s}$ as $400 \mathrm{~m}$ ). Bradley (2013) does not have a GMPE for subduction zone earthquakes.

"Probability of inducing liquefaction based on New Zealand magnitude-bounded relationships from Maurer et al. (2015).

earthquakes, and minor liquefaction occurred during the 13 June 2011 earthquake (hereafter also referred to as September 2010, February 2011, and June 2011 events). The level of shaking experienced was different for each event in the area (note that peak ground accelerations [PGAs] used here were recorded at LINC seismic station, which is located $\sim 3 \mathrm{~km}$ away from the sites and sits on similar soil type): (a) the epicenter of the September 2010 $M_{\mathrm{w}} 7.1$ earthquake was $29 \mathrm{~km}$ away (closest distance to the Greendale fault is $\sim 15 \mathrm{~km}$ ) and produced PGA of $0.42 g$ in Lincoln (magnitude-weighted $\mathrm{PGA}_{7.5}$ of $0.38 g$; Table 1; epicentral distance to LINC station is $27 \mathrm{~km}$ ); (b) the epicenter of the February $2011 M_{\mathrm{w}} 6.2$ earthquake was $17 \mathrm{~km}$ away from the study sites and generated $0.12 \mathrm{~g}$ PGA in Lincoln $\left(\mathrm{PGA}_{7.5}\right.$ of $0.07 g$; Table 1; epicentral distance to LINC station is $18 \mathrm{~km}$ ); and (c) the epicenter of the 13 June $2011 M_{\mathrm{w}} 6.0$ earthquake was $22 \mathrm{~km}$ away and generated PGA of $0.06 \mathrm{~g}$ at Lincoln $\left(\mathrm{PGA}_{7.5}\right.$ of $0.04 \mathrm{~g}$; Table 1; epicentral distance to LINC station is $23 \mathrm{~km}$ ).

2. The study sites are located at similar distances from both major earthquake sources (i.e., from Greendale fault, source for the 4 September 2010 earthquake; and from the 22 February 2011 earthquake), and thus can provide insights into feature type and size for distal sites of liquefaction as well as the relationship between distance of surface expression of liquefaction and earthquake magnitude.

3. The study sites are on farmland with few buildings and therefore favorable both for conducting ground investigations and using aerial photography and lidar for mapping surface features.

4. The study sites were visited during the postearthquake reconnaissance allowing preliminary field data to be gathered immediately after the liquefaction events. This information was supplemented by excellent photographic and observational records by the landowner of the Hardwick site.

Our study has reviewed pre-2010 aerial photography and aerial photography and lidar-derived digital elevation models (DEMs) taken after the events; produced detailed local geomorphic maps; excavated and logged shallow ( 1-1.5 m) trenches; and analyzed handcored sediments to a depth of $5 \mathrm{~m}$. This detailed data collection has allowed us to document the characteristics of the 2010-2011 earthquake-induced liquefaction features in the Lincoln area, to recognize paleoliquefaction features, and to compare paleoliquefaction features with modern features at the same sites. We further present preliminary inferences about the sediment layers that liquefied during the earthquake sequence and on potential correlations between the geomorphic elements of the fluvial sedimentary environments and the distribution of the 2010-2011 liquefaction features. We also estimate the age of paleoliquefaction features discovered at the two study sites near Lincoln and discuss possible earthquake sources of the paleoearthquake(s) that caused paleoliquefaction. The data allow us to make recommenda- 
tions regarding future paleoliquefaction studies in the Christchurch area. With this study of liquefaction sites in the Canterbury area and future studies in other low seismicity areas, we aim to improve understanding of earthquake potential and reduce uncertainties in the seismic-hazard model of New Zealand. The newly gained data and understanding can be used to calibrate current earthquake-hazard models of the area, including the assessment of recurrence of nearby medium-size "floating earthquakes" (sourced from blind faults or otherwise unmapped faults not represented in the active fault maps). Also, the new information will assist in the production of appropriate probabilistic liquefaction maps through calibration against the prehistoric record.

\section{Quaternary Geology}

\section{Sedimentary Context}

The Canterbury Plains are underlain by Quaternary fluvioglacial outwash and marine sediments. Eustatic sealevel changes in association with glacial-interglacial cycles have led to a complex interfingering of terrestrial and marine deposits (Brown et al., 1988; Field et al., 1989; Brown and Weeber, 1992; Browne and Naish, 2003). Most of the sediment at and near the coast is fine grained (sand, silt, clay, and peat) and water saturated (high water table). As a consequence, most sediment is characterized by high-to-moderate liquefaction susceptibility (Elder et al., 1991).

Our field area contains sedimentary deposits of the Springston Formation (Brown and Weeber, 1992) that are associated with the evolution of the Waimakariri River. Postglacial surfaces are found near the lower Waimakariri River in the form of several very young river terraces and abandoned river channels. Some currently abandoned channels can be traced through the wider area of Christchurch and were probably active within the last 500 years (Forsyth et al., 2008). Older channels suggest that, during their formation, the Waimakariri River (or a branch of it) flowed to the south of Banks Peninsula, reaching the sea in the region of the shores of the present Lake Ellesmere (Fig. 1). At present, the Halswell River is a much lower discharge river than the Waimakariri and flows in one of these relict channels, previously occupied by the Waimakariri River (Forsyth et al., 2008).

\section{Tectonic Context}

The current tectonic environment of the Canterbury Plains is characterized by reverse (anticlinal growth and blind, or partially buried, thrusts and backthrusts) and strike-slip faults in a compressional zone east of the plate-boundary fault, the Alpine fault (Forsyth et al., 2008; Campbell et al., 2012; Fig. 1). The Pacific and Australian plates are converging obliquely at 35-40 mm/year (Beavan et al., 2007), with up to 80\% of the total rate being accommodated by the strike-slip/reverse Alpine fault (e.g., Beavan et al., 2007; Sutherland et al., 2007; Wallace et al., 2007) and, farther north, by the Marlborough strike-slip fault system (Hope, Clarence, Awatere, and Wairau faults; Langridge et al. 2003; Fig. 1b). The Canterbury Plains experience moderate strain rates $(\sim 2 \mathrm{~mm} / \mathrm{yr}$; Wallace et al., 2007) and low levels of seismicity. Tectonic contraction in the region is accommodated by a series of blocks rooted in an 12-km-deep decollement (Campbell et al., 2012, and references therein). Each block contains northeast-striking reverse faults with a frontal thrust (e.g., Springbank and Hororata faults) and internal synthetic and antithetic thrusts. Strike-slip faults with an east-west trend (e.g., Ashley and Greendale faults) represent transfer zones linking thrust zones (Campbell et al., 2012). All these active faults respond to a uniform regional stress field with maximum horizontal compressive stress oriented $115^{\circ} \pm 5^{\circ}$ (Sibson et al., 2011). Although the presence of faults in the plains is well known, not all active faults in the plains have surface expression and thus have not been mapped. This was demonstrated by the 2010 Darfield earthquake, which occurred along a previously unknown active fault, the Greendale fault (Quigley et al., 2012; Fig. 1). However, prior to 2010, it was known that unmapped faults have to be present in the plains to accommodate the $\sim 2 \mathrm{~mm} / \mathrm{yr}$ fraction of the total deformation across the plate boundary that could not be assigned to known faults (Stirling et al., 2012). Because of the poor or subtle surface expression of most of the Canterbury Plains' faults (Forsyth et al., 2008), little is known on the timing of fault events in the area. Paleoearthquake histories are only known for a few faults such as the Porters Pass fault (Howard et al., 2005), Ashley fault (Sisson et al., 2001), and Greendale fault (Hornblow et al., 2014).

The Canterbury earthquake sequence (Fig. 1) started with the $M_{\mathrm{w}} 7.1$ Darfield earthquake on 4 September 2010 (Bannister and Gledhill, 2012). A series of aftershocks followed until 22 February 2011, when the most devastating $M_{\mathrm{w}} 6.2$ Christchurch earthquake occurred (Kaiser et al., 2012), resulting in 185 fatalities and substantial financial losses. More aftershocks followed, with a significant one $\left(M_{\mathrm{w}} 6.0\right)$ on 13 June. During December 2011, seismicity shifted offshore and included two events with $M_{\mathrm{w}} 5.8$ and $M_{\mathrm{w}}$ 5.9. Strong ground motions recorded during the 22 February event relate to proximity to fault rupture (Beavan et al., 2012) and fault directivity of seismic energy toward the city (Holden, 2011).

\section{Liquefaction in the Canterbury Plains}

Five damaging historic earthquakes occurred within $\sim 150 \mathrm{~km}$ of Christchurch between 1869 and 1922 (Downes and Yetton, 2012); however, no liquefaction was reported in Christchurch following any of these events. Liquefaction was reported in the residential areas of Kaiapoi and Belfast, north of Christchurch following the $1901 M_{\mathrm{w}} 6.8$ Cheviot earthquake (Berrill et al., 1994). Modified Mercalli intensity 7 shaking and infrastructure damage (including collapse of the Christchurch cathedral spire) was reported in the $1869 \sim M_{\mathrm{w}} 4.8$ Christchurch earthquake (Downes and Yetton, 2012). Following this earthquake, it was observed by a local resident that "the tide runs higher up the Heathcote River than formerly" (Heathcote River is located within Christchurch City), suggesting that set- 
tlement potentially induced by liquefaction may have occurred (Downes and Yetton, 2012). The $1870 M_{\mathrm{w}} \sim 5.7$ Lake Ellesmere, $1888 M_{\mathrm{w}} \sim 7.2$ Hope fault, $1901 M_{\mathrm{w}} \sim 6.8$ Cheviot, and $1922 M_{\mathrm{w}} \sim 6.4$ Motunau, North Canterbury, earthquakes all caused strong shaking and infrastructure damage in Christchurch and other areas of Canterbury (Downes and Yetton, 2012), but no liquefaction was reported for our study site.

Liquefaction induced by the 4 September 2010 Darfield and the 22 February 2011 Christchurch earthquakes and other aftershocks produced sand volcanoes or blows and related ground failures, including fissures, lateral spreading, and subsidence and uplift. Sand blows ranged in size from tens of centimeters to meters, and concentrations of sand blows occurred over large areas up to $\sim 1 \mathrm{~km}^{2}$, with a variety of expressions of liquefaction occurring over a wider area of $40 \times 20 \mathrm{~km}^{2}(\mathrm{Cu}-$ brinovski and Green, 2010; Cubrinovski et al., 2011; Ward et al., 2011; Almond et al., 2012; Kaiser et al., 2012; Reid et al., 2012; Quigley et al., 2013; Bastin et al., 2015; Townsend et al., 2016). As many as 10 distinct liquefaction episodes were reported for a site in Avonside in eastern Christchurch that is underlain by very liquefiable sediment (Quigley et al., 2013). As demonstrated by liquefaction-related lateral spreading and subsidence (up to $1.5 \mathrm{~m}$ of horizontal and $0.5 \mathrm{~m}$ vertical displacement recorded in eastern Christchurch; Bastin et al., 2015) and increased flooding and marine inundation in parts of eastern Christchurch (Hughes et al., 2015), earthquakeinduced liquefaction poses a significant hazard with long-term economic and societal implications.

\section{Methods}

The Hardwick and Marchand sites near Lincoln were selected for detailed field investigations. To document liquefaction at our study sites, we first interviewed witnesses about their observations during the 2010-2011 events. Those observations provided firsthand accounts of the formation of sand blows, blisters (raised mounds by liquefied sand injected within the very near surface), and fissures and were used to select sites for further investigation. The landowners at the Hardwick site photographed and measured many of the surface features of liquefaction on their property.

Second, we produced a detailed geomorphic map and updated the existing map of the occurrence of sand blows and other surface effects of liquefaction (Townsend et al., 2016) for selected areas at both sites (Fig. 2). The mapping used pre-2010 and modern aerial photos; analyzed DEMs derived from lidar surveys acquired after each of the Christchurch earthquakes; and consulted unpublished geomorphic maps (David Barrell, personal comm., 2013) (for more information see (E) Figs. S1 and S2, available in the electronic supplement to this article).

Third, we excavated 11 paleoseismic trenches at selected locations, 7 at the Hardwick site (trenches HWK 1, 2, 3, 4a, 4, 5, and 6; see full trench logs and unit descriptions in (E) Figs. S3-S10 and (E) Tables S1-S7), and 4 at the Marchand site (trenches MAR 1, 2, 3, and 4; see full trench logs and unit descriptions in (E) Figs. S11-S14 and (E) Tables S8-S10).
Nine trenches were excavated across the 2010-2011 liquefaction features to document their subsurface geometry and the properties of sediments hosting the liquefaction features. Two trenches were excavated in an area with no surface effects of liquefaction, primarily to assess whether the sedimentary units are different from the sites where sand blows formed at the surface (those trenches were not logged in detail, but relevant information on sediments was collected). The trenches were excavated down to the water table $(\sim 1.2-1.5 \mathrm{~m}$ deep). The walls and floors of 9 of the 11 trenches were smoothed and cleaned, and a square grid with a spacing of $1 \mathrm{~m}$ was placed along the walls and on parts of the floor. In areas that required more detailed study, a $0.5 \mathrm{~m}$ grid was used. After gridding, the walls and parts of the floors were photographed and logged, and figures of the stratigraphic units and the liquefaction features were produced, including a description of the sediments and locations of organic samples collected for radiocarbon dating. Liquefaction feature characteristics such as size and azimuth of lineations were recorded (ㄹ) Tables S11 and S12 and (E) Figs. S16 and S17).

To complement the information on the sedimentary sequence from the trenches and to obtain information on the liquefaction source layer, we extracted $\sim 18 \mathrm{~m}$ of intact core (in sections of 0.7-1 $\mathrm{m}$ length) with a 5-cm-diameter round-rod piston corer, fitted with a core catcher that can retrieve watersaturated sands. The cores were obtained from the bottom of several trenches. We visually inspected each core for liquefaction features and described the sedimentary units (E) Figs. S18-S21).

Organic matter samples were collected and dated at the Rafter Radiocarbon Laboratory, GNS Science. Radiocarbon ages were calibrated (E) Table S13) and stratigraphic sequences were analyzed with the Bayesian analysis tools of OxCal v.4.2.4 (Bronk Ramsey, 2009), using the southern hemisphere calibration curve SHCal13 (Hogg et al., 2013; (E) Figs. S22-S24). Uncertainties at $2 \sigma$ are given throughout this report, and calibrated ages are provided in A.D./B.C. format. Particle-size analysis was undertaken with a Micrometrics Saturn DigiSizer II 5205 at the University of Canterbury.

\section{Geomorphic Map}

The study sites are on a late-Holocene low-lying $(<10 \mathrm{~m}$ above mean sea level) floodplain-delta complex about 6-8 km north of Lake Ellesmere. The floodplain-delta complex was formed by old distributary channels of the Waimakariri River, which now flows to the sea north of Christchurch. The Halswell River currently follows one of the ancient Waimakariri channels (Figs. 1 and 2).

The DEMs reveal subtle topography and define the different geomorphic elements of the landscape (Fig. 2 and (E) Figs. S1 and S2). The low topographic features (dark blue to light green colors) comprise flood basin and interchannel surfaces of relatively flat alluvial surfaces in the Waimakariri/ Halswell basin, channels associated with the most recent course of the Waimakariri River, an earlier generation of paleochannels inferred to be relict meanders of the Waimakariri River, and swales of point bars associated with relict meanders. 

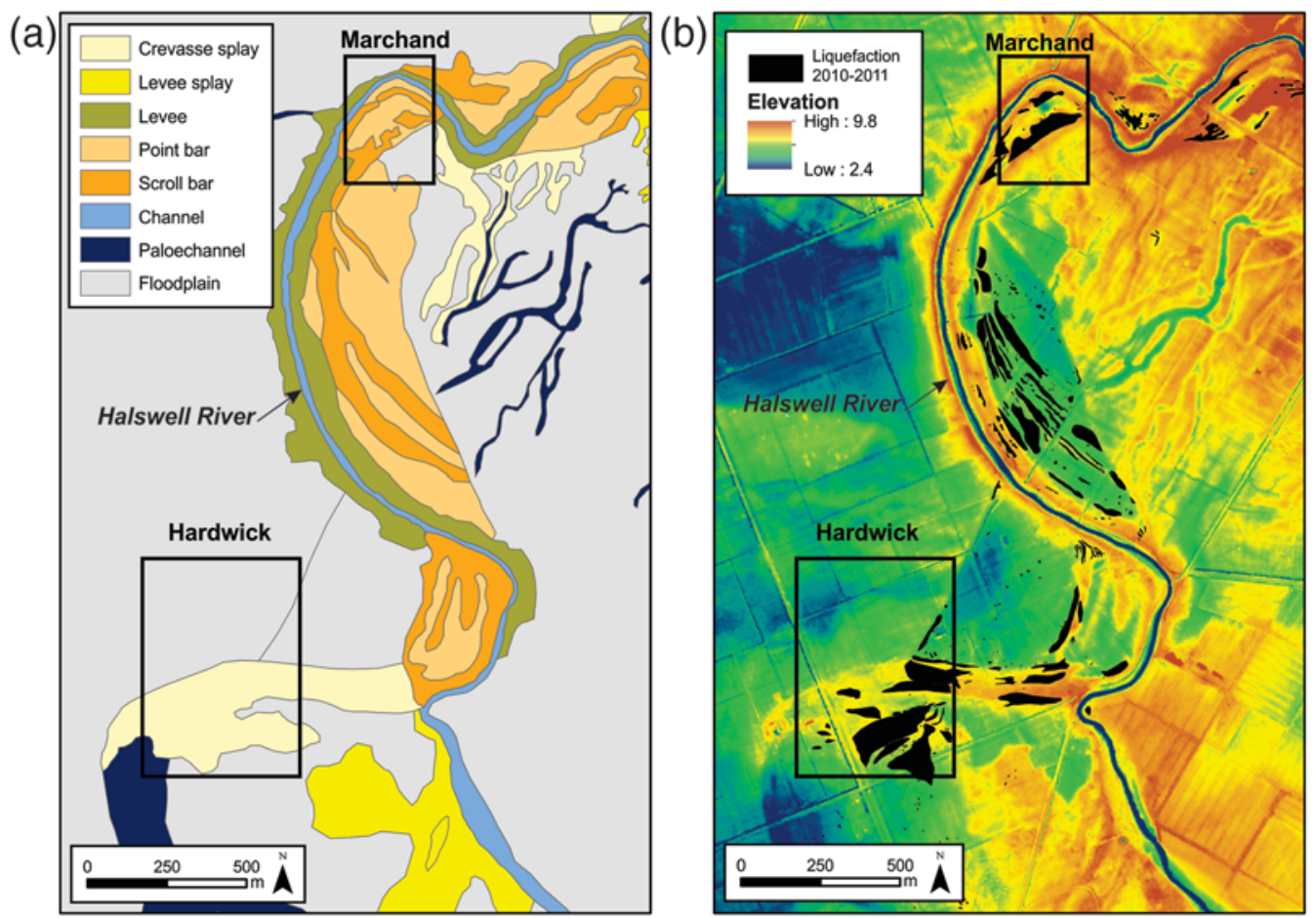

Figure 2. (a) Geomorphic map of the wider study area and (b) digital elevation model (DEM) from light detection and ranging (lidar) with the locations of the 2010-2011 liquefaction sand blows (black polygons).

The highest topographic features (yellow to red colors in Fig. 2b and (E) Fig. S2) represent raised crevasse splays (also known as floodplain splays) and channels or levees. The raised channels of the Halswell River and its levee system are at a distinctly higher topographic level than the surrounding floodplain. This indicates that the Halswell River must have gone through a depositional phase at this location to build such prominent levee architecture. The crevasse splays may be associated with either the current Halswell River or the Waimakariri River, given that some of them are eroded by the relict meander channels and some are filling those channels.

The two sites selected for detailed study, the Hardwick and the Marchand sites (Figs. 1 and 2), exemplify slightly different types of geomorphic settings, as described as described in The Hardwick Site and The Marchand Site sections.

\section{The Hardwick Site}

\section{Geomorphology}

The Hardwick site occurs on a relict meander (Figs. 2 and 3). The lidar imagery clearly illustrates a leftward bend set within a floodplain, identified by light green colors in Figures 2 and 3. The downstream, southern part of the now abandoned and infilled meander is at a lower elevation (blue color) than the floodplain, as would be expected, but the upstream part stands above the floodplain (yellow-orange colors). This elevated area corresponds to a levee-crevasse splay system of a later paleochannel or perhaps the Halswell River.
Surface Expression of the 2010-2011 Liquefaction

At the Hardwick site, the 2010-2011 sand blows appear to be spatially associated with levee and crevasse splay deposits that overtopped the river channel (Figs. 2 and 3). The lower part of the old alluvial plain outside the channel (blue and dark green colors, Fig. 3) was subject to only minor liquefaction. In addition, some sand blows formed on the inner side of the abandoned meander at its southernmost section (south of the Hardwick's site; Fig. 2b).

The liquefaction features located above or spatially associated with the crevasse splay consisted mainly of sand blows that are aligned and coalesce along fissures to form sand ridges. Individual sand blows were up to $40 \mathrm{~cm}$ high and $5 \mathrm{~m}$ wide. Aligned and coalesced sand blows formed sand fissures up to $10 \mathrm{~m}$ long (Figs. 3 and 4). Some of the sand fissures overlapped, creating composite sand fissures up to $30 \mathrm{~m}$ long (E) Fig. S2). Most of the fissures and composite fissures formed lineaments that were $100+\mathrm{m}$ long. Many of the fissures were aligned subparallel to the shape of the outer edge of the abandoned meander. Other fissures also seem to be associated with elevated areas within the crevasse splay. Liquefaction did not occur in areas of lower elevation within the crevasse splay. In some locations, sand of different colors and grain sizes vented to the surface (Fig. 4) suggesting different source layers. Other sand blows that were not aligned but were associated with ground deformation (location $4 \mathrm{~b}$ in Fig. 3) occurred at the edge of the crevasse splay and/or immediately adjacent to, but not within, the crevasse splay. At these locations, we identified blisters, which are liquefaction features 

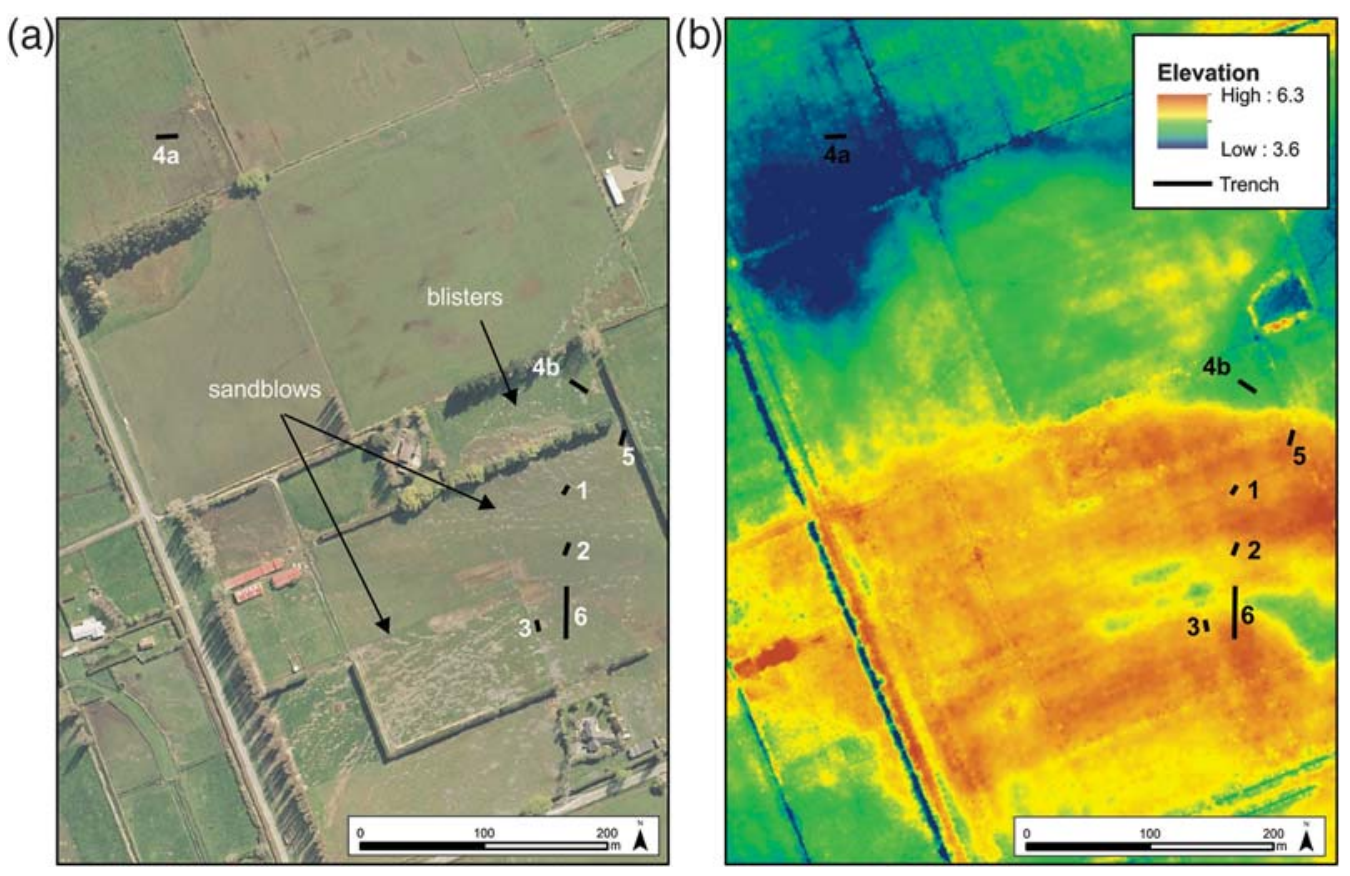

Figure 3. (a) Orthophotograph and (b) DEM from the lidar data of the Hardwick site showing the location of the trenches. Liquefaction sand blows can be observed on the orthophotograph. The location of the blisters is also shown.

resulting from intrusion of sand beneath near-surface soil horizons, raising the ground surface to form mounds up to $20 \mathrm{~cm}$ high and $2.5 \mathrm{~m}$ in diameter. Although most of the injected sand beneath the blisters did not reach the surface, a small proportion did so through ruptures at points of strong surface inflection.

\section{0-2011 Liquefaction and Paleoliquefaction}

Features Exposed in the Hardwick Trenches

In the Hardwick trenches, we observed several types of liquefaction features in the vertical section that were associated with the 2010-2011 events. These included sand blows, dikes, and blisters. We also identified paleoliquefaction features, including an eroded sand blow and several dikes. In this section, we present exemplars of the liquefaction features revealed in the trenches in the context of the stratigraphy and geomorphology. (E) Full trench and core logs are available in the electronic supplement (Figs. S3-S10, S18, and S19; Tables S1-S7).

Location of Trenches. Seven trenches were excavated at the Hardwick site (Fig. 3). Trenches HWK 1, 3, and 6 were excavated across liquefaction features that formed during the 2010-2011 earthquakes and are located on higher topography within the crevasse splay of the Waimakariri-Halswell floodplain in the area where the crevasse splay clearly overlays the infilled meander channel. Trench HWK 5 is located in a similar setting but closer to the edge of the crevasse splay and potentially above the older meander channel. All these trenches were excavated across fissures with aligned sand blows. Trench HWK $4 \mathrm{~b}$ was excavated beyond or at the very northern edge of the crevasse splay in an area of low topography, where lique- faction caused ground deformation in the form of subcircular mounds with small amounts of sand escaping to the surface (blisters; see detailed description in the MAR 4 trench section).

Trenches HWK 2 and 4a were excavated in areas that had no surface expression of liquefaction. Trench HWK 2 corresponded with a low topographic point within the central part of the abandoned channel overlain by the crevasse splay among trenches HWK 1, 3, and 6. Trench HWK 4a was located on the lower topographic levels of the Waimakariri-Halswell floodplain away from the old meander channel. The trench was intended to allow contrasts in sedimentology between areas of presence and absence of surface expression of liquefaction to be identified. Unfortunately, a shallow perched water table caused the trench walls to collapse, so it could not be analyzed in detail. However, some samples for radiocarbon dating and particle-size analysis were collected prior to collapse.

Core Samples. To further understand the sedimentary characteristics of this site, including potential identification of the source layers of liquefied sand, we extracted (1) $4 \mathrm{~m}$ of core below the HWK 6 trench at vertical meter mark 7 along the trench and starting from the trench floor (from 1.4 to $5 \mathrm{~m}$ depth below ground surface) (core HWK 6-1; see core log in HWK 6 trench $\log$ in (E) Figs. S9 and S10 and core description in (E) Fig. S19) and (2) $2 \mathrm{~m}$ of core from below the HWK 5 trench at vertical meter mark 3 (core HWK 5-1; see core log in HWK 5 trench $\log$ in (E) Fig. S8 and core description in (E) Fig. S18).

Sedimentary Units at Hardwick Site. We grouped the sedimentary units of the trenches at Hardwick into three macrounits (e.g., see trench HWK 6 and core HWK 6-1 in Figs. 5 and 6 and $(E)$ Figs. S9, S10, and S19). This grouping is based 
(a)

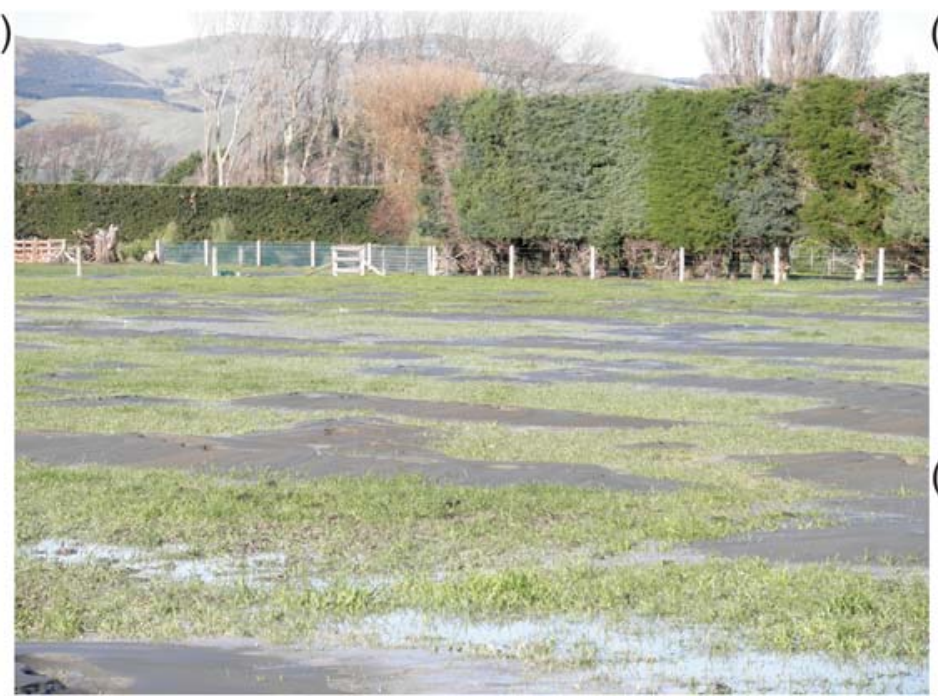

(b)

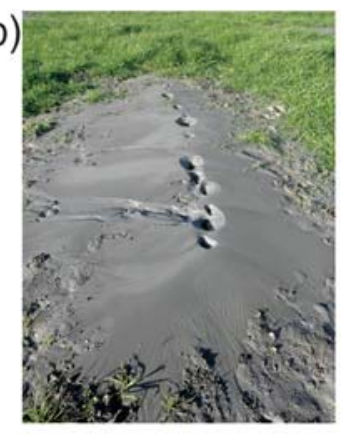

(c)

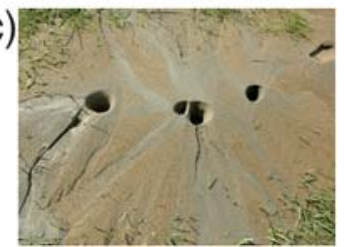

Figure 4. Photographs of sand blows at Hardwick site taken on 4 September $2010 \sim 12$ hours after the Darfield earthquake. (a) Field of fissures with coalescent sand blows. (b) Detail of individual fissure with coalescent sand blows (approximately $2 \mathrm{~m}$ long). (c) Detail of sand blows with two different types of ejected or vented sand (different colors). The two types of sand are well sorted and stratigraphically separate in profile, suggesting that there is little to no incorporation of sediment from layers through which the slurry of water and entrained sediment flowed on its way to the surface. Therefore, the sand composing the two layers of the sand blow was derived from different source layers. (Photos courtesy of Caroline Hardwick).

mainly on textural similarities, and incorporates soil stratigraphy. It aims to associate macrounits with sedimentary environments (although this association has not been possible for all macrounits within the scope of this study). Detailed descriptions for individual layers within the macrounits are available in (E) Tables S1-S7.

Macrounit 1, the uppermost unit, is characterized by alternating loamy silt and very fine sand layers and also the organic-rich topsoil. The unit varies from yellowish brown to gray and includes common redox segregations. Soil stratigraphic features, including truncated root pseudomorphs (redox features) and relict surface-horizon soil structure, indicate that this is a composite depositional unit.

Macrounit 2 underlies macrounit 1 and is characterized by a gray, silty upper part with common redox segregations, which grade downward into very fine to fine sand. The upper 20-30 cm, where intact, may be organic rich and includes peat layers and root remains. The underlying fine sand is moderately sorted, and grains are subrounded.

Macrounit 3 is distinctly different from the upper units. It consists mainly of medium sand, a coarser texture than that found in macrounits 1 and 2. Macrounit 3 is massive, and grains are very well sorted and rounded. Overall the unit has a gray color in its upper part, grading downward to olive gray at the base. This macrounit is exposed only in the HWK 6 deepest core sections (below the floor of the HWK 6 trench).

Along a transect between trenches HWK 3-HWK 6 and trench HWK 4b (Fig. 3), the correlation of changes in the thickness of macrounit 1 with the changes in topography was used to infer that macrounit 1 represents the deposits of the crevasse splay lobe. A thinning of macrounit 1 (from 1.2 to $0.8 \mathrm{~m}$ ) to the north was obvious in the walls of trench
HWK 6 (see (E) Figs. S9 and S10). The surface elevation also decreased as the crevasse splay lobe terminates against a stream channel. The contact between macrounits 1 (crevasse splay) and 2 (channel fill; see below) is erosional, although remnants of an organic-rich horizon (a paleosol) in the top of macrounit 2 are preserved (e.g., Fig. 6a-d). Detrital organics occur as lenses above the contact (e.g., Fig. 6d); and, in the southern end of trench HWK 6, a subfossil tree was exposed in the base of macrounit 1 (E) Fig. S9). The top of macrounit 2 is a gray silt with common, coarse, orange-brown, spherical mottles. One sample from within $30 \mathrm{~cm}$ of the top of macrounit 2 yielded the conventional radiocarbon age (calibrated ages can be found in (E) Table S13) of $2004 \pm 18 \mathrm{yr}$ B.P. (sample HWK T6-C5; Fig. 6 and (E) Fig. S9). Two samples toward the middle-to-lower section of macrounit 2 within the cores yield ages of $2939 \pm 20$ yr B.P. (sample HWK 6-C1T2-S1, core HWK 6 C1; (E) Fig. S10) and $398 \pm 17$ yr B.P. (sample HWK 6-C2-T2-S1, core HWK 6 C2; (E) Fig. S10), the latter one being an obvious outlier. Part of a small tree rooted in the very top of macrounit 2 and in growth position gave an age of $721 \pm 18$ yr B.P. (HWK T6-C12; Fig. 5 and (E) Fig. S10). Above the unconformity (at the base of macrounit 1), detrital organics (undifferentiated plant material extracted from the sediment) yielded ages of $668 \pm 18 \mathrm{yr}$ B.P., $641 \pm 20$ yr B.P., and $641 \pm 19$ yr B.P. (samples HWK T6-C7, HWK T6-C10, and HWK T6-C14, respectively; (E) Fig. S9). The contact between macrounits 2 and 3 was identified in core samples at $\sim 4.7 \mathrm{~m}$ depth but had no age constraints; the base of macrounit 3 extends beyond $5.1 \mathrm{~m}$ depth (E) Fig. S10).

At trench HWK 2, on the margin between the abandoned meander and another lobe of the crevasse splay to the north, 

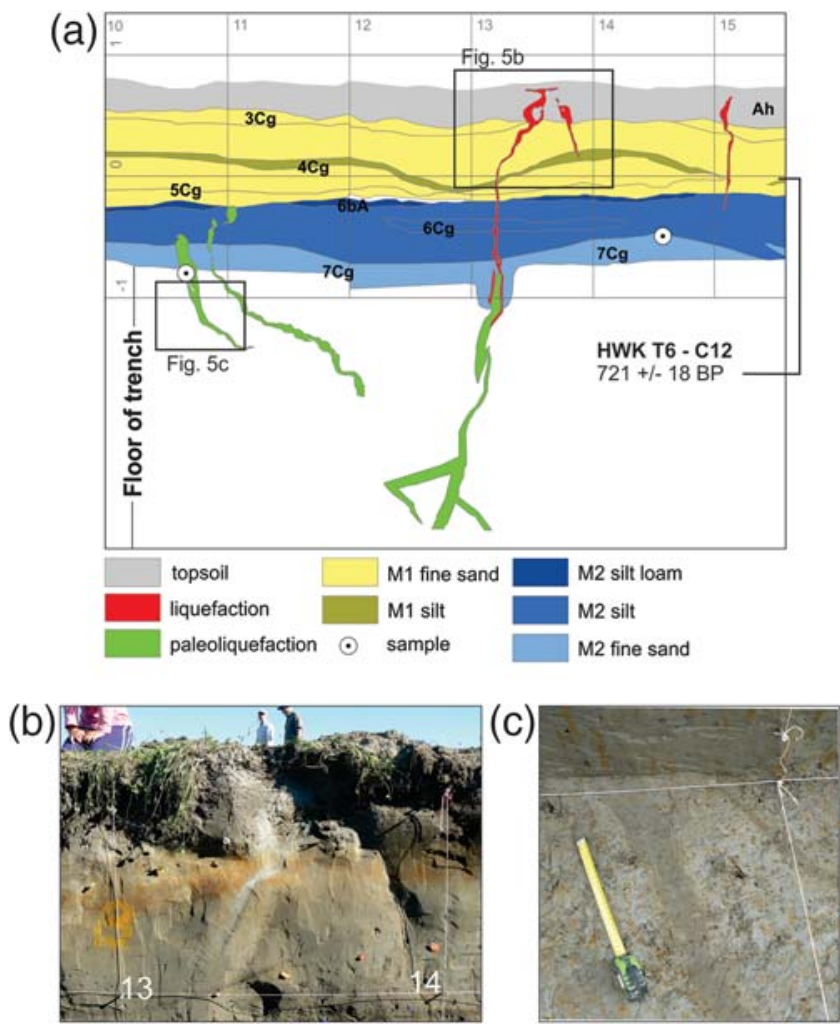

Figure 5. HWK 6 trench west wall. (a) Section of trench $\log$ (vertical lines 10-15.5). For radiocarbon sample HWK T6-C12, only the correlative stratigraphic position is shown (for the full trench log, including location of sample HWK T6-C12, see (E) Fig. S10). (b) Example of a 2010-2011 liquefaction dike and sand blow (see location of photograph in a). (c) Paleoliquefaction dikes at the same location exposed on the trench floor and wall. Note that the 2010-2011 dikes have been reinjected along the paleoliquefaction dikes (see also a). See Figure 3 for trench location. See (E) Figure S10 for exact location of sample HWK T6-C12.

macrounit 1 had thickened again to $1.53 \mathrm{~m}$ ((E) Table S2). The top of macrounit 2 (exposed at $1.53-1.85 \mathrm{~m}$ depth) was a distinct, intensely reduced blue-gray, massive silt with no visible organics. Farther north, at trench HWK 1 (located in the center of the crevasse splay lobe), the stratigraphy was similar to trenches HWK 3 and HWK 6. At trench HWK 5, the contact between macrounits 1 and 2 appeared to be nonerosive (at $\sim 1.5 \mathrm{~m}$ depth). A peat was preserved below the contact at $1.6 \mathrm{~m}$ depth. A radiocarbon sample from the top of the peat yielded $628 \pm 18$ yr B.P. (sample HWK 5-C1; Fig. 7 and (E) Fig. S8), similar to the detrital organics in macrounit 1 at trench HWK 6. Coring to $3.7 \mathrm{~m}$ depth failed to reach the base of macrounit 2. The most northerly trench (trench HWK 4b; (E) Fig. S6), situated beyond the northern limit of the crevasse splay lobe, exposed only macrounit 2 .

In summary, macrounit 1 contributes to the higher topography associated with the crevasse splay deposits. Deposition was preceded by erosion, ripping up material from underlying deposits, and burying and killing trees. Macrounit 2 is associated with a pre-existing channel fill-floodplain sediment association. Deposition of macrounit 2 had ceased around
3000 yr B.P., and soils were developing in it until the deposition of macrounit 1 at $\sim 650 \mathrm{yr}$ B.P. The coarser sands of macrounit 3 suggest a higher-energy fluvial environment, but the geomorphic context is now obscured by the overlying materials. Further work on grain size, sedimentary fabric, and dating is currently being undertaken to better interpret this unit.

Representative Liquefaction Features from Three Trenches. We present here exemplars of liquefaction and paleoliquefaction features observed in some sections of the trenches at the Hardwick site.

HWK 6 Trench. Trench HWK 6 was $34 \mathrm{~m}$ long and 1.5-1.8 m deep (Figs. 5 and 6; for full trench logs see (E) Figs. S9 and S10). Both trench walls, HWK 6E and HWK 6W, were logged in detail between vertical lines 1 and 23. Some areas with liquefaction features were mapped at 1:10 scale, and other areas were mapped at 1:20 scale. Gradual collapse of the walls between vertical lines 23 and 32 precluded detailed logging, and only the contacts of major units were mapped at 2-m-spacing vertical lines.

The 2010-2011 liquefaction features exposed in this trench were sand blows and dikes (Figs. 5 and 6). The trench was excavated at right angles to the sand fissures to expose the true cross-section dimensions and shape of individual sand blows and dikes. The spacing between sand blows ranged between 4 and $14 \mathrm{~m}$ along the trench. At the surface, the sand blows exposed in this trench have widths between 0.5 and $2 \mathrm{~m}$ and heights between 5 and $10 \mathrm{~cm}$ (for data on sand-blow sizes, see also (E) Table S11 and (E) Fig. S15). These values are slightly modified from the original dimensions by erosion due to rainfall, wind, and trampling by cattle. However, no plowing occurred after the formation of the sand blows and, as a consequence, the measurements are closely representative of the original sizes. Each sand blow was associated with dikes with average widths, typically ranging between 3 and $20 \mathrm{~mm}$ (maximum of $100 \mathrm{~mm}$; for data on dike widths and sand blow sizes, see also (E) Table S11 and (E) Fig. S15). The dikes could be followed from the trench floor to the ground surface. The root of the dikes was not observed in the trench.

Figures 5 and 6 show examples of the upper part of a dike (close to the surface) and a sand blow. On the west wall, at vertical line 13.4 (Fig. 5b), we observed the upper part of a dike that feeds into a sand blow $20 \mathrm{~cm}$ west of the trench. This dike changes in width along its length, a common feature for most of the dikes exposed at this site. We assigned an average width and a range to each dike (E) Table S11 and (E) Fig. S15). The dike also splays into two branches close to the trench floor, where it follows the outside edges of an old dike (described below). In the east wall, at vertical line 18 (Fig. 6a), a small sand blow shows the typical convex shape, slightly eroded from the original shape. The dike feeding this sand blow is very thin: $10 \mathrm{~mm}$ wide close to the floor of the trench but only $3 \mathrm{~mm}$ wide for most of its length.

As measured from aerial photography, the trend of the larger sand-blow fissures close to trench HWK 6 ranges from 
(a)

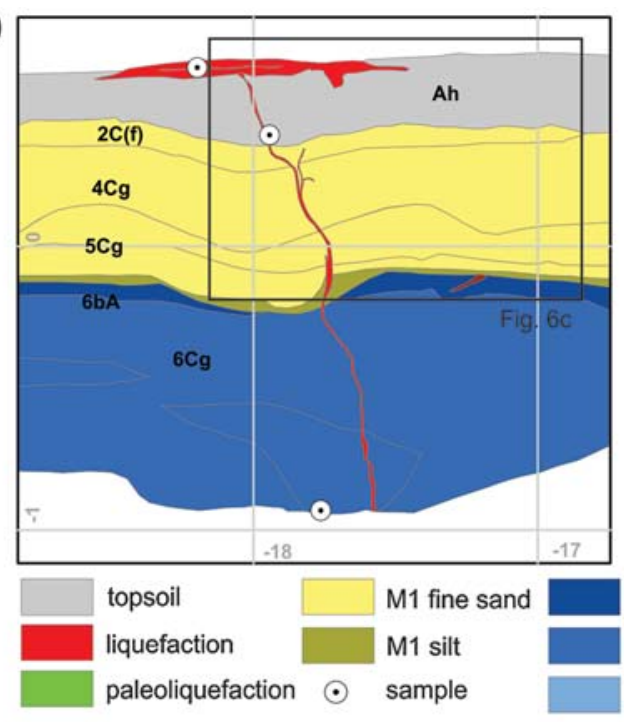

(b)

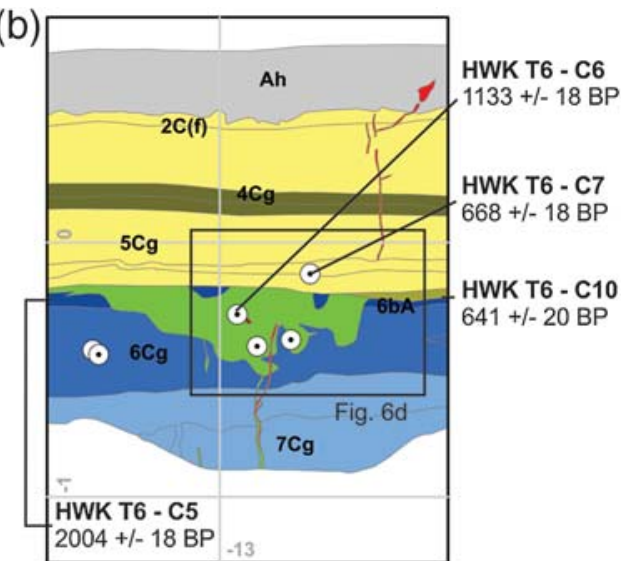

M2 silt loam

M2 silt

M2 fine sand (c)

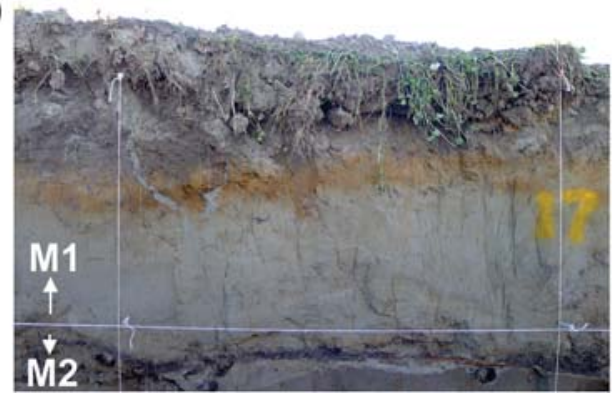

(d)

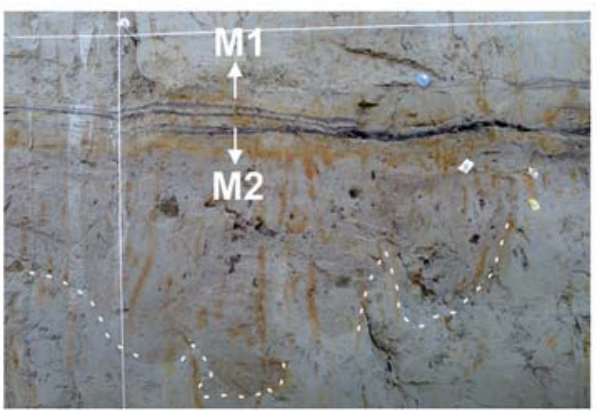

Figure 6. HWK 6 trench east wall. (a) Section of trench wall log (vertical lines 19-17; for the full trench log see (E) Fig. S9). (b) Trench wall $\log$ (vertical lines 14-12). For radiocarbon sample HWK T6-C5, only the correlative stratigraphic position is shown (see full trench log for sample location). (c) Photograph of a 2010-2011 liquefaction dike and sand volcano (see location of trench in Fig. 3). (d) Photograph of paleoliquefaction features at the same location. An old dike and a buried and eroded sand blow (filling tree root space) are displayed (see location in b). The dashed white line delineates parts of the paleosand-blow margin. The presence of an erosional unconformity between units $6 \mathrm{bA}$ and $5 \mathrm{Cg}$ provides evidence that the upper part of the paleosand blow has been eroded. The sand-blow age is constrained by the ages of layer $6 \mathrm{bA}$ (paleosol), the base of layer $5 \mathrm{Cg}$, and by a radiocarbon sample taken from within the sand blow. Old and new dikes follow the same path. See Figure 3 for trench location. (E) See Figure S9 for exact location of sample HWK T6-C5 and HWK T6-C10.

$\mathrm{N} 50^{\circ} \mathrm{E}$ to $\mathrm{N} 75^{\circ} \mathrm{E}$ and other smaller fissures trend east-west and $\mathrm{N} 20^{\circ} \mathrm{E}$. The strike of individual dikes measured within the trench walls and floor display two orientations: $\mathrm{N} 20^{\circ} \mathrm{E}-\mathrm{N} 50^{\circ} \mathrm{E}$ and $\mathrm{N} 130^{\circ} \mathrm{E}-\mathrm{N} 150^{\circ} \mathrm{E}$ (ㅌ) Fig. S16 and () Table S12).

Several paleoliquefaction features were also observed on both walls of the HWK 6 trench. Between vertical lines 10 and 14 on the western wall and continuing across the trench floor, at least three paleoliquefaction dikes could be observed (Fig. 5a). The dikes are weathered and redox segregations (mottles) cross the dike margins, indicating that they were formed well before the 2010-2011 earthquakes. In contrast, the 2010-2011 dikes are unweathered and are not mottled. The paleodikes are slightly wider than the 2010-2011 dikes (average width of $4 \mathrm{~cm}$ compared with $2 \mathrm{~cm}$; (E) Table S11). The paleodikes intrude into macrounit 2 but not macrounit 1 , and so the age of macrounit 1 establishes a minimum for the penultimate shaking event that formed the paleodikes. As can be seen at vertical line 13, the outer margins of the paleodikes were used by the 2010 2011 dikes as injection pathways (Fig. 5a).
On the eastern wall at vertical line 13, a paleosand blow appears eroded at the unconformity between macrounits 1 and 2, so that only the lower part of it has been preserved (Fig. 6b,d). The preserved part has a very convoluted lower boundary. It is likely that the slurry of water and sand intruded along the roots of a tree or into cavities left by rotting roots. A modern analog to this feature was observed farther north along the same trench wall (at vertical line 23 on the eastern wall; (E) Fig. S9) where the base of the sand blow had an irregular shape, filling root cavities within the topsoil. The paleosand blow is connected to a paleodike that was used as the injection pathway during the 2010-2011 liquefaction events.

HWK 5 Trench. The HWK 5 trench was excavated across an N90 E-trending fissure with coalescent sand blows. The trench was $6.5 \mathrm{~m}$ long and $1.5 \mathrm{~m}$ deep (Fig. 7a). An additional pit was hand excavated at the bottom of the trench to $2.5 \mathrm{~m}$ depth. Sediment cores were extracted from the bottom of the trench down to $5.5 \mathrm{~m}$ (for full trench and core logs 


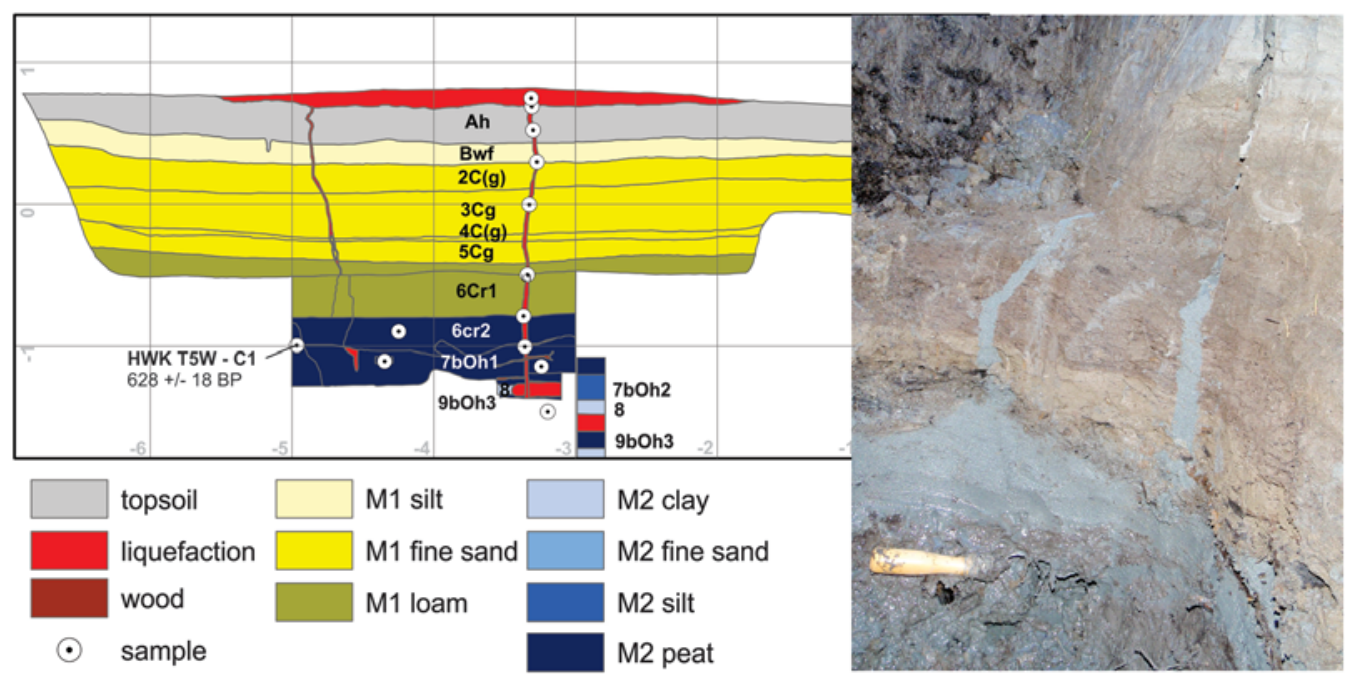

Figure 7. HWK 5 trench west wall. (a) Trench wall log (for the full trench log see (E) Fig. S8). (b) Photograph of liquefaction sill and dike (gray sands) from the 2010-2011 earthquakes. Photograph is from a small hole excavated at the trench floor. The photograph shows a wall perpendicular to the west wall at approximately vertical line 3. This exposure was not logged. See Figure 3 for trench location.

and the sedimentary unit description, see (E) Figs. S7, S8, S18, and (E) Table S6).

All liquefaction features exposed in the trench were produced by the 2010-2011 earthquakes and consisted of (1) a compound sand blow that was $3.4 \mathrm{~m}$ wide and $20 \mathrm{~cm}$ thick (Fig. 7a), (2) two thin $(2-10 \mathrm{~mm})$ dikes feeding the sand blow, and (3) an $\sim 10$-cm-thick sill at the base of the trench (Fig. 7a,b). The compound sand blow formed during several of the earthquakes in the 2010-2011 sequence.

The subvertical-to-vertical dikes feeding the sand blow had strikes of $\mathrm{N} 114^{\circ} \mathrm{E}$ (dike at vertical line 5) and $\mathrm{N} 90^{\circ} \mathrm{E}-$ $\mathrm{N} 100^{\circ} \mathrm{E}$ (dike at vertical line 3 ). Those orientations corroborate the trends of liquefaction lineaments observed in this area from aerial photography (Fig. 3a), in which $\mathrm{N} 90^{\circ} \mathrm{E}$ is a dominant trend displayed by numerous lineaments that exceeded $100 \mathrm{~m}$ in length (composed of aligned fissures with coalescent sand blows). Also in the aerial photo, shorter $(<50 \mathrm{~m})$ lineaments with an $\sim \mathrm{N} 120^{\circ} \mathrm{E}$ trend can be observed. The edge of the paleochannel at this location is oriented $\mathrm{N} 90^{\circ} \mathrm{E}-\mathrm{N} 110^{\circ} \mathrm{E}$. The dikes were observed cutting all the way from the trench floor through macrounit 1 to the ground surface (Fig. 7a). The dike seemed to be rooted in a sandy layer at the base of the trench, but further excavations and coring confirmed that the layer was a sill and that the source sands that liquefied must have been deeper than the trench floor (i.e., $>1.5 \mathrm{~m}$ ).

The sill at the base of the trench was injected into the upper part of macrounit 2 (inside the uppermost organic layers 7bOh1-9bOh3; Fig. 7a). The sill was observed at the bottom of the hand-excavated pit on the western and northern trench walls. The corner of the western and northern walls of the small pit is shown in Figure 7b, where two vertical dikes can be observed rooted into the sill (note that those dikes are on the northern wall of the small excavation and thus do not appear on the western wall $\log$ ). The base of the sill was difficult to reach because of the presence of the water table in the bottom of the small hand-dug pit, but core HWK 5 confirmed that it was a sill rather than the top of the source sand for the liquefaction features. Units $7 \mathrm{bOh} 2-9 \mathrm{bOh} 3$ are loose in nature, with large pieces of wood and remnants of sedge vegetation. Following liquefaction, the pressurized slurry of water and sand could have easily injected horizontally along the weaker partings within this principally organic unit, thereby locally forming sills.

HWK 3 Trench. The HWK 3 trench was excavated across one of the largest sand blows, with dimension of $4.4+\mathrm{m}$ width and at least $0.35 \mathrm{~m}$ height. The most striking feature at this location was a small, 1-m-wide collapse crater (Fig. 8). This crater formed a few weeks after liquefaction occurred (Caroline Hardwick, personal comm., 2012). The western trench wall exposed a complex dike structure with three thick dikes (up to $90 \mathrm{~mm}$ wide) connecting to a sill (up to $240 \mathrm{~mm}$ thick). Collapse occurred in the area occupied by the sill. At this location, there is no connection between the sill and the sand blow; the connection was observed along strike, as can be seen on the eastern wall () Fig. S5).

The surface sand fissure has a trend of $\mathrm{N} 45^{\circ} \mathrm{E}$ and is the same fissure as the one exposed in trench HWK 6. The strike of the dike ranges from $\mathrm{N} 72^{\circ} \mathrm{E}$ to $\mathrm{N} 87^{\circ} \mathrm{E}$ (with dips between $55^{\circ}$ and $90^{\circ}$ toward both the northwest and southeast; (E) Table S12) and is more east-west than the mean $\mathrm{N} 45^{\circ} \mathrm{E}$ of the fissure at this location.

\section{The Marchand Site}

\section{Geomorphology}

The Marchand site is located within a meander bend of the Halswell River (Figs. 2 and 9). The subtle topography displays high areas (1+ m; in yellow and orange; Fig. 9b) adjacent to low areas (green and blue), parallel and subparallel to the current river channel. The high-standing geomorphic 
(a)

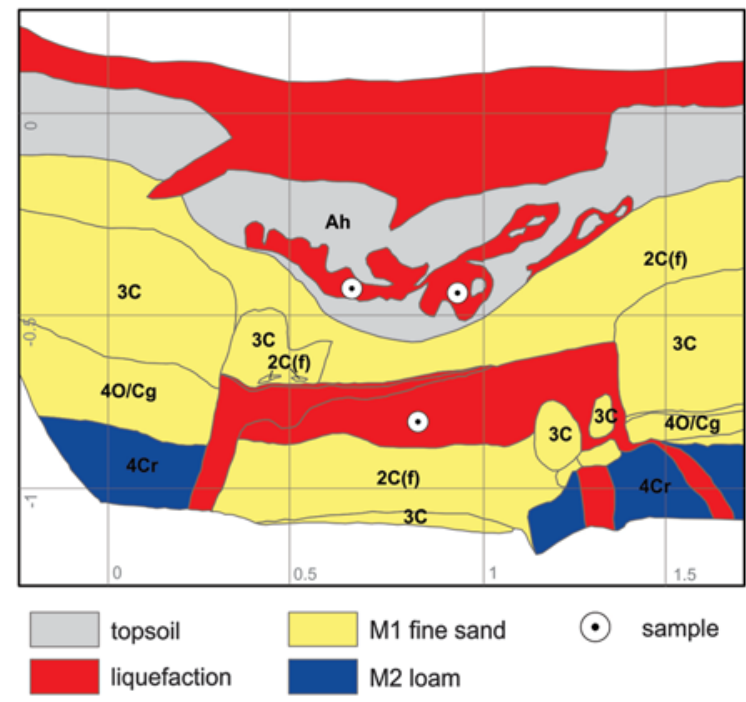

(b)

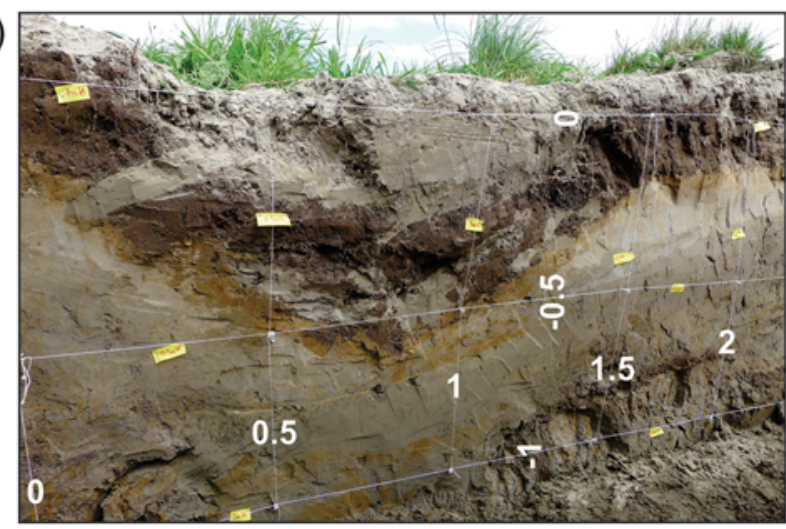

Figure 8. HWK 3 trench west wall. (a) Trench wall $\log$ (for the full trench $\log$ see (E) Fig. S4). The middle section of the sedimentary package has subsided, forming a small collapse structure or graben. At that location there is a thick $(\sim 25 \mathrm{~cm})$ liquefaction sill. (b) Photograph of the trench wall. See Figure 3 for trench location.

features are a levee and two main scroll bars. The low areas are the swales between scroll bars.

\section{Surface Expression of the 2010-2011 Liquefaction}

Liquefaction features produced during the 2010-2011 earthquakes-including sand blows, sand fissures, and blisters-formed along the higher elevation scroll bars and were absent in the intervening low areas (Fig. 9a). The sand fissures and aligned sand blows were subparallel to the scroll bars and river channel. Some of the fissures were up to $50 \mathrm{~m}$ in length and composed of coalescent sand blows up to $4 \mathrm{~m}$ wide. Mounds associated with blisters were up to $2 \mathrm{~m}$ in diameter, and some were associated with ejected sand or sand blows.

2010-2011 Liquefaction and Paleoliquefaction Features Exposed in the Marchand Trenches

In the Marchand trenches, several types of 2010-2011 liquefaction features were exposed, including cross-sectional views of sand blows, dikes, and blisters. We also found several paleoliquefaction dikes. In this section, we show the location of the trenches with respect to the geomorphic features described above. In addition, we describe and estimate the ages of sedimentary units found in the Marchand trenches and present the best examples of liquefaction features.

Location of Trenches. Four trenches at the Marchand site were excavated across the 2010-2011 liquefaction features (Fig. 9). Trenches MAR 1 and MAR 4 were located on a scroll bar within $25-50 \mathrm{~m}$ of the inside of a meander bend of the Halswell River. Trenches MAR 2 and MAR 3 were located on a more distal and broader scroll bar on the inside of the meander bend about $90 \mathrm{~m}$ from the Halswell River. Substantial liquefaction occurred at the highest point of this older bar, but it could not be studied because of the presence of buildings. Also trench MAR 2 collapsed during excavation and could not be studied. Two cores at the base of trenches 1 and 4 reached depths of $\sim 4$ and $3 \mathrm{~m}$.

Sedimentary Units at Marchand Site. Sedimentary sequences in the MAR 1 and MAR 4 trenches, located on the outer scroll bar closest to the current river channel, were similar. We recognized two macrounits in each, labeled 1a and 2a (Fig. 11; see full trench logs in (E) Figs. S11, S12, and S14; see trench unit descriptions in (E) Tables S8 and S10; see core descriptions in (E) Figs. S20 and S21). The use of similar nomenclature for macrounits at the Hardwick and Marchand sites does not imply a stratigraphic correlation between the two sites. Also, the "a" designation distinguishes macrounits on the outer scroll bar from those on the inner scroll bars (labeled "b"; see below) at the Marchand site. Macrounit 1a was characterized by very fine sediments, comprising silt loams, loamy silts, and very fine sands. The upper boundary of macrounit $2 \mathrm{a}$ at 1.5 or $1.8 \mathrm{~m}$ depth for trenches MAR 1 and MAR 4, respectively, was defined by a woody peat up to $70 \mathrm{~cm}$ thick within macrounit 2 found in the cores. Below this layer, sediments of macrounit $2 \mathrm{a}$ alternated between silts and medium sands with some thin fine sand beds. The lowermost $60 \mathrm{~cm}$ of the unit, from 4.1 to $4.7 \mathrm{~m}$ depth (revealed at trench MAR 1) was a distinctive olive-brown to yellowbrown medium fine sand. This sand was the same color and grain size as the sand in the sand blows observed on the outer scroll bar and within the blister that we excavated at trench MAR 4

A charcoal sample from $1.3 \mathrm{~m}$ depth in macrounit 1a yielded a radiocarbon age of $861 \pm 18 \mathrm{yr}$ B.P. (sample MAR T1-C6; see MAR 1 trench log in (E) Fig. S12 and radiocarbon age data in (E) Table S13), and a sample from near the base of the peat marking the top of macrounit $2 \mathrm{a}$ at the same site provided an age of $1009 \pm 18 \mathrm{yr}$ B.P. (sample MAR 1-C1-T2-S1; (E) Fig. S11 and (E) Table S13). In MAR 4 trench, a sample from the top of the same peat yielded an age of $709 \pm 19$ yr B.P. (sample MAR 4-C1-T1; (E) Fig. S14 and (E) Table S13). A thinner peat layer ( $5 \mathrm{~cm}$ thick) at $3.06 \mathrm{~m}$ 

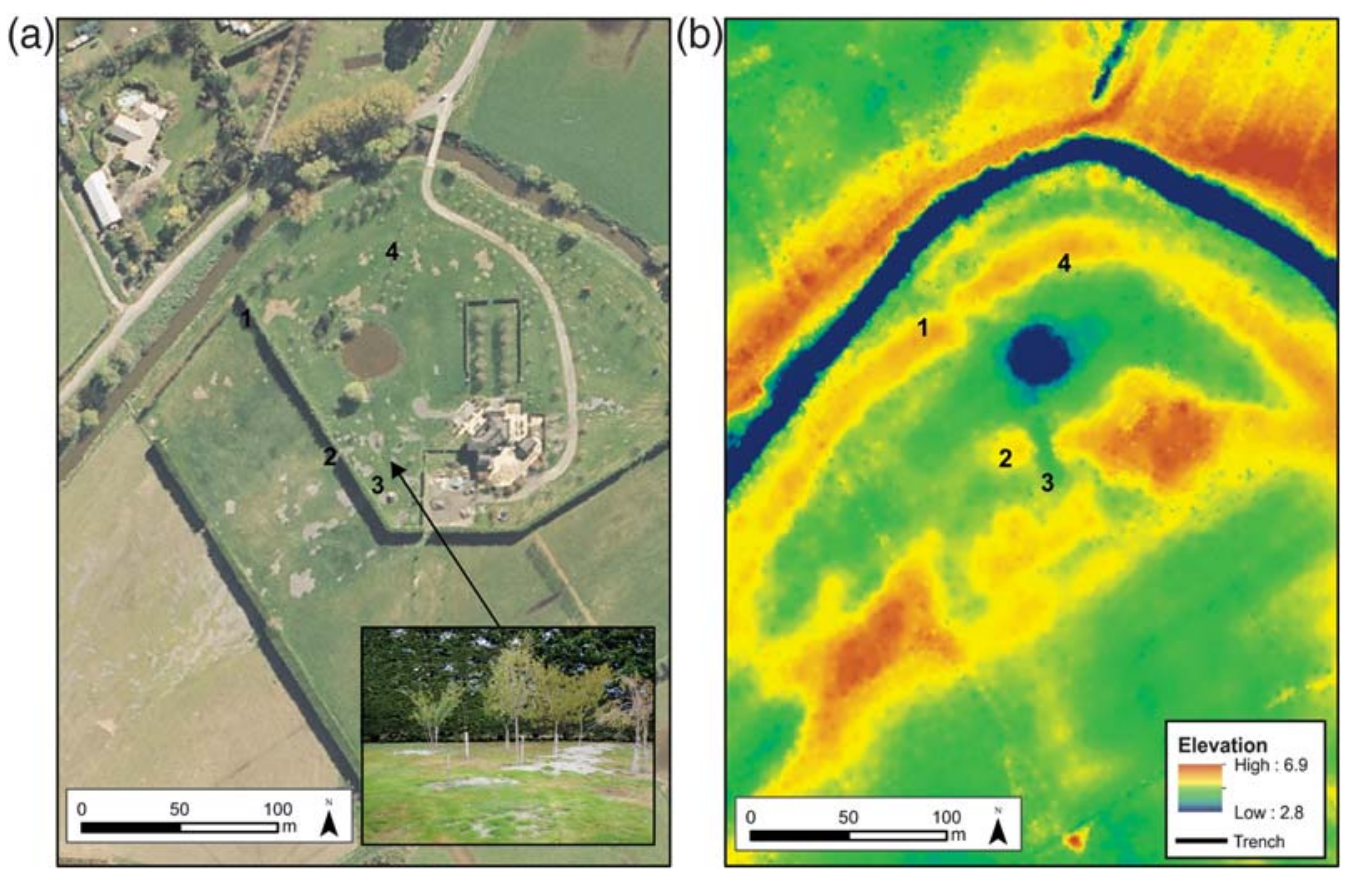

Figure 9. (a) Orthophotograph (provided by Canterbury Regional Council) and (b) DEM from lidar data of the Marchand site showing the location of the trenches. Liquefaction sand blows can be observed on the orthophotograph. Inset photograph with arrow shows the surface expression of fissures and coalescent sand blows along fissures (photograph taken in March 2012).

depth gave an age of $1918 \pm 20 \mathrm{yr}$ B.P. (sample MAR 4-C1T2-S1; (E) Fig. S14 and (E) Table S13).

Sedimentary units exposed in the MAR 3 trench, located on the inner scroll bar, were similar to macrounit 1a; however, the time-transgressive nature of sedimentation across meander scroll sequences reduced our confidence in the strength of this stratigraphic correlation. Consequently, we have provisionally labeled this unit macrounit $1 \mathrm{~b}$ until additional data become available. A relatively old age of $1038 \pm 20 \mathrm{yr}$ B.P. from only $0.6 \mathrm{~m}$ depth (sample MAR T3-C2 in Fig. 10a and (E) Fig. S13; (E) Table S13) affirms the need for a cautious approach to stratigraphic correlation. No deeper stratigraphic units were defined during this study.

\section{Representative Liquefaction Features from Two Trenches}

MAR 3 Trench. MAR 3 trench was $4 \mathrm{~m}$ long and $1.2 \mathrm{~m}$ deep and excavated across a sand blow of a $\mathrm{N} 35^{\circ} \mathrm{E}$-trending fissure of coalescent sand blows. Three walls of the trench were logged with $1 \times 1 \mathrm{~m}^{2}$ and $0.5 \times 0.5 \mathrm{~m}^{2}$ grids (Fig. 10a and $($ ) Fig. S13). The walls perpendicular to the fissure (northeast and southwest) exposed a subvertical, 10-100-mm-wide dike running from the trench floor and connecting with the sand blow at the surface. The north wall, parallel to the trend of the fissure, exposed a series of dikes (40-100 mm wide) with a subhorizontal apparent dip (true dip $28^{\circ}-58^{\circ} \mathrm{NW}$ ). These dikes had strikes of $\mathrm{N} 30^{\circ} \mathrm{E}-\mathrm{N} 50^{\circ} \mathrm{E}$ and $\mathrm{N} 160^{\circ} \mathrm{E}$ ((E) Table S12 and (E) Fig. S17).

Two generations of dikes were observed in the trench: 2010-2011 dikes and paleodikes (Fig. 10c). The former recently injected sand dikes were unweathered and had sharp margins and clear connections both to the sand blow exposed at the surface and to each other. The paleodikes were weath- ered and had clear but irregular margins crosscut by redox segregations. The paleodikes were locally crosscut by the 2010-2011 dikes. In some places, the 2010-2011 dikes were intruded along the margins of the older dikes. The exposed sand blow was $4 \mathrm{~m}$ wide and $20 \mathrm{~cm}$ high. Depositional features, such as fine crossbedding, were observed. Two main depositional units belonging to the 2010-2011 events could be distinguished by the presence of tree leaves deposited on the sand blow prior to the second event (Fig. 10b).

MAR 4 trench. MAR 4 trench was $1.4 \mathrm{~m}$ deep and $5 \mathrm{~m}$ long and was excavated across one of the circular-tosubcircular mounds that were formed during the 2010-2011 liquefaction events (Fig. 9). Some of these mounds, such as the one studied in the MAR 4 trench, were also associated with sand vented on the surface. We describe these types of features as liquefaction blisters, and they seem to occur in areas of thick $(>0.5 \mathrm{~m})$ topsoil.

The liquefaction blister exposed in the MAR 4 trench consisted of two shallow dipping $\left(0^{\circ}-45^{\circ}\right.$ dip both northwest and southeast), $\mathrm{N} 25^{\circ} \mathrm{E}-\mathrm{N} 70^{\circ} \mathrm{E}$ striking, thick (up to $25 \mathrm{~cm}$ wide) dikes injected into the topsoil (Fig. 11a-d), and sand blows formed where dikes reached the surface. The local thickening of the topsoil layer caused by sand injection created the mound or blister on the surface. The sand dike beneath the blister was $7 \mathrm{~cm}$ wide and could be traced downsection through the alluvial sequence to the bottom of the trench (Fig. 11a,e). The liquefied sand layer that was the source of the sand dikes was not observed in the trench. The dikes forming the blister exhibited laminations (defined by subtle changes in grain size) in the connection between the blister dikes and the thin feeding 
(a)

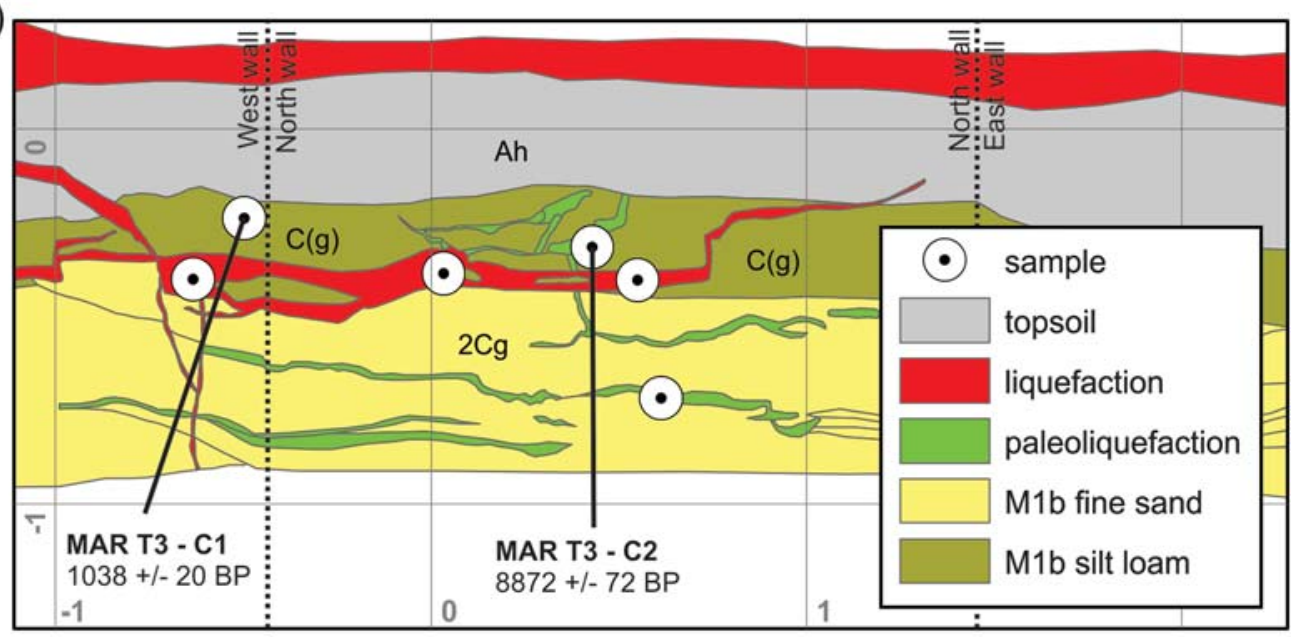

(b)

(c)
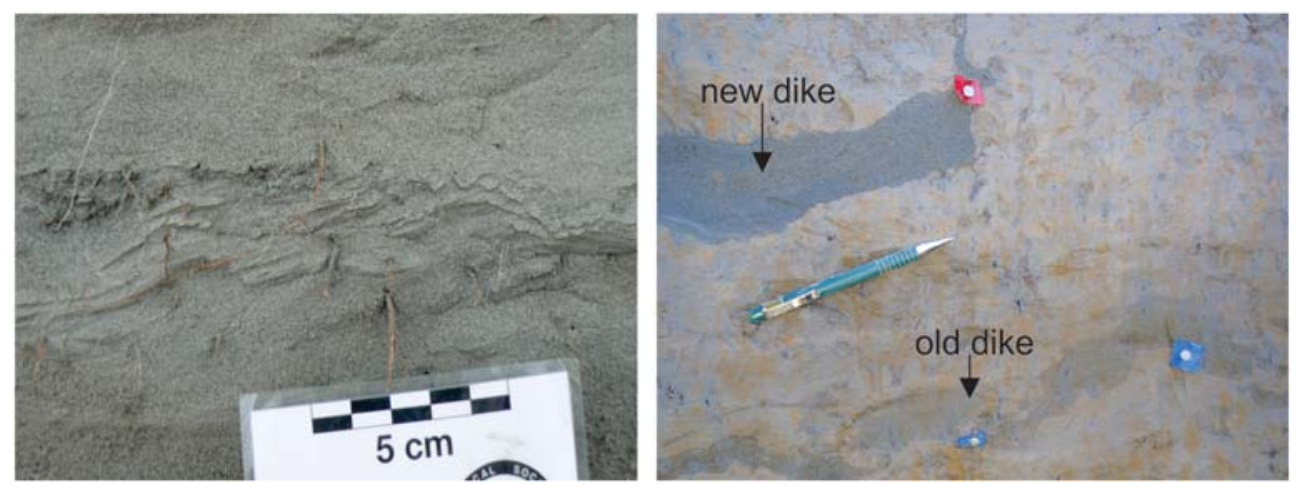

Figure 10. MAR 3 trench combined west-north-east walls (note that three different walls are displayed in the figure). (a) Trench log (for the full trench $\log$, see (E) Fig. S13). The 2010-2011 liquefaction, as well as paleoliquefaction features, were observed in the MAR 3 trench. Note that dikes appear subhorizontal in the north trench wall because the wall is subparallel to the dike strikes (see dike azimuths in (E) Fig. S17). Modern dikes cut through paleodikes, indicating a younger relative age. The maximum age of the paleoliquefaction is constrained by the age of the host sediment (unit $\mathrm{C}(\mathrm{g})$ ). (b) Detail of the 2010-2011 sand blow on the west wall. Tree leaves were found at the contact between the September 2010 and February 2011 events. (c) Detail of the 2010-2011 dike and paleodikes on the north wall. Note the weathering features in the paleodikes. See Figure 9 for trench location.

dike (Fig. 11c) that were parallel to the dike margins (Fig. 11d). The lamination suggests laminar flow during injection of the slurry. Trench HWK $4 \mathrm{~b}$ at the Hardwick site was excavated across a blister that displayed similar characteristics (see (E) Fig. S6).

A small graben-like structure associated with a subvertical sand dike below the blister was observed at the base of the MAR 4 trench wall (Fig. 11a,e). However, with the limited exposure, it is difficult to know whether this structure is an elongated graben or a circular, or semicircular, collapse structure. The trend of dikes in the collapse area is to be all subparallel to the scroll bar, suggesting that the collapse is likely to be elongated. This structure occurs close to the river bank, and thus it may be associated with lateral spreading. It is also possible that the collapse is associated with consolidation and/or evacuation of an underlying liquefiable sand reservoir, and thus its shape would then be determined by the volume of the evacuated sand. The geometric relationships between faulting, dike intrusion, and sedimentation suggest that the small graben formed during the 2010-2011 earthquake sequence. No prior liquefaction event(s) could be identified in the MAR 4 trench.

\section{Discussion}

Liquefaction

Influence of the Sedimentary Environment in the Distribution of Liquefaction

Association between Meander Scroll Bars and

Liquefaction. There is a strong spatial correlation between particular environments within the alluvial system and the occurrence of the 2010-2011 liquefaction. Therefore, detailed mapping of geologic deposits (assisted by geomorphic mapping with high-resolution topographic maps) may help to identify sites that liquefied in the past and that may be prone to liquefaction in the future. Our results also corroborate previous findings that liquefaction susceptibility is strongly linked to the environment of deposition (e.g., Youd and Hoose, 1977; Youd, 


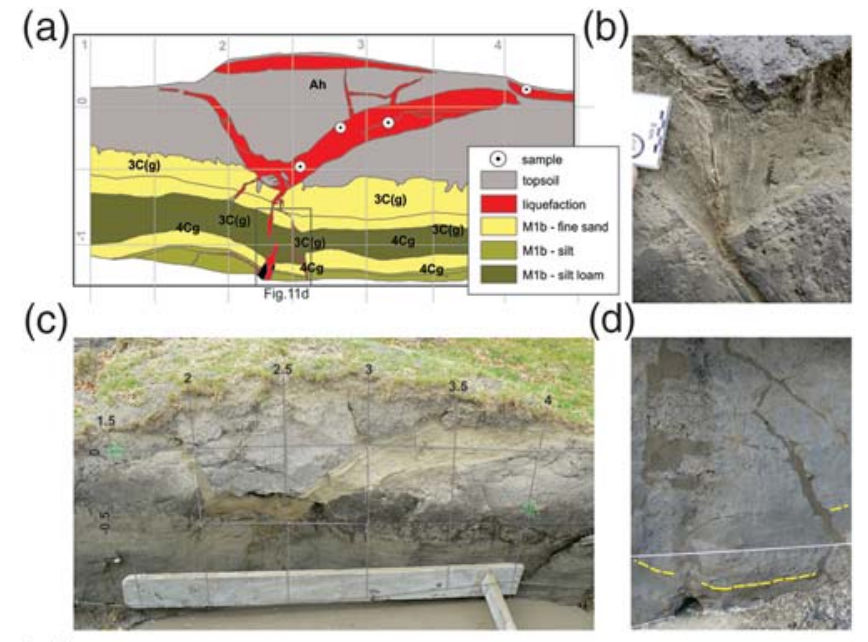

(e)

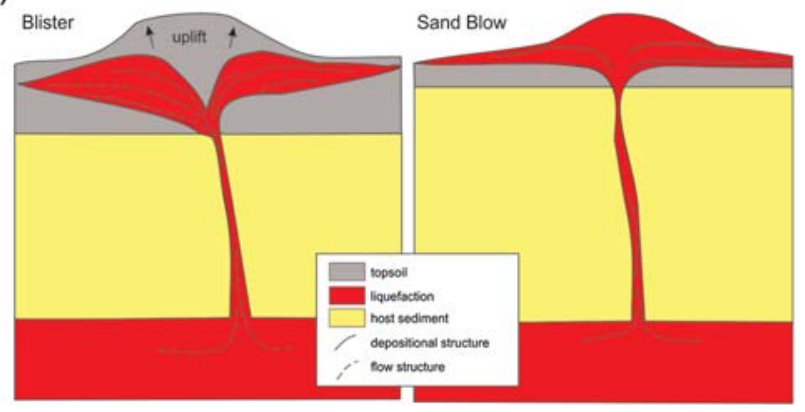

Figure 11. MAR 4 trench east wall. (a) Trench $\log$ (for the full trench $\log$ and core location, see (E) Fig. S14). Note the downward drag of layers toward the center, under the blister, and the mechanical offsets (similar to faults) displayed in the lower part of the wall (collapse structure; ground failure). (b) Detail of flow structures in the dikes. (c) Photograph of upper meter of the trench wall where the blister was found. (d) Detail of the collapse structure (graben; see subsidence of layer highlighted with a yellow dashed line and dikes intruding along the "faults"). (e) Generic sketch of blister in comparison with a sand blow. In the blister, the sills and low-angle dikes split the soil layers in close proximity to the ground and uplift the ground surface. On occasions, some of the sand can extrude to the surface.

1984; Tuttle and Atkinson, 2010; Holzer et al., 2011; Tuttle and Hartleb, 2012; Civico et al., 2015). At Lincoln, we are in the process of investigating the characteristics of the sediment that liquefied and its depositional environments to strengthen these correlations. Here, we summarize our observations and preliminary interpretations.

There is a very strong spatial correlation between liquefaction features and the ridges of scroll bars on the inside bends of meander loops. This correlation has been observed at the Marchand site (Figs. 2 and 9) and in several areas along the Halswell River channel. The Marchand site excavations also exposed paleoliquefaction dikes at the same location as the 2010-2011 liquefaction features. The orientations of the sand fissures (Figs. 2 and 9) and the feeder dikes (E) Table S12 and (E) Fig. S17) are subparallel to the scroll bar trends and the river channel.

Liquefaction associated with the inner side of meanders has been widely reported in New Zealand (Quigley et al.,
2013; Bastin et al., 2015) and elsewhere (e.g., Youd and Hoose, 1977; Tuttle, 1999; Holzer et al., 2011). Liquefaction occurs here because (1) the sediments are typically younger and less consolidated in the inner meanders and (2) during strong horizontal ground motions, the inner banks of meanders are not confined (i.e., the arching geometry of the inner meanders allows for lateral spreading), whereas outer meanders are confined. These are characteristics specific to the Marchand site.

At the Marchand site, we also observe that surface expressions of liquefaction are confined to meander scroll bars (ridges) and are not present in the swales. The source layer for the liquefied sands was not exposed at this site, but liquefaction of the MAR 2 trench floor at $<1 \mathrm{~m}$ depth during excavation (caused by the vibration of the digger) suggests that it could be quite shallow. The water table at the time of excavations was $\sim 1.5 \mathrm{~m}$ deep at the Marchand site. In point-bar systems, sedimentary deposition processes, and thus the properties of sediments such as grain-size distribution, void ratio, and permeability, and their depth below the surface, differ between ridges (scroll bars) and swales (Pranter et al., 2007; Van de Lageweg et al., 2014). The ridges are underlain by sandy point-bar deposits that are close to the surface, whereas sandy deposits are much deeper beneath swales and are overlain by relatively thick fine-grained and organic-rich deposit. These observations agree with the explanation that sand dikes and blows form along the crests of scroll bar deposits due to the liquefaction susceptibility of underlying point-bar deposits and the relatively thinness of the top stratum.

Association among Abandoned Meander Channels, Abandoned Point Bars, Crevasse Splays, and Liquefaction. At the Hardwick site, because the crevasse splay overtops an old, infilled meander channel and its scroll bars, the correlation between the spatial distribution of liquefaction and the geomorphic elements of the alluvial system is less clear. Grain-size analysis, together with analysis of the liquefaction pattern, suggests that liquefaction at the Hardwick site could be associated with the channel and point-bar deposits. Preliminary comparisons of particle-size distribution between the sand-blow material and deeper sections of the longest core (HWK 6-1) (Fig. 12) suggest that the sand blows could be sourced from a layer at 4+ $\mathrm{m}$ depth (macrounit 2; e.g., sample HWK 6 C1-T2-60 in tube 2 at $60 \mathrm{~cm}$ depth in (E) Fig. S19b, which has a similar particle-size distribution as the liquefied sands in Fig. 12, was located $4 \mathrm{~m}$ depth). Based on unit descriptions and the geomorphic setting, that layer is likely to consist of channel bed or point-bar deposits (sand) overlain by channel infill deposits (silt) (macrounit 2), which in turn are overlain by crevasse splay deposits (macrounit 1). The liquefaction fissures show several trends (surface expression, Figs. 2, 3, and (E) Fig. S1; dike trends, (E) Fig. S16), with two predominant orientations that are subparallel to the old meander channel and to the inferred orientation of its scroll bar complex. Liquefaction features often form along the margins of an abandoned channel deposit where fine-grained deposits overlie 


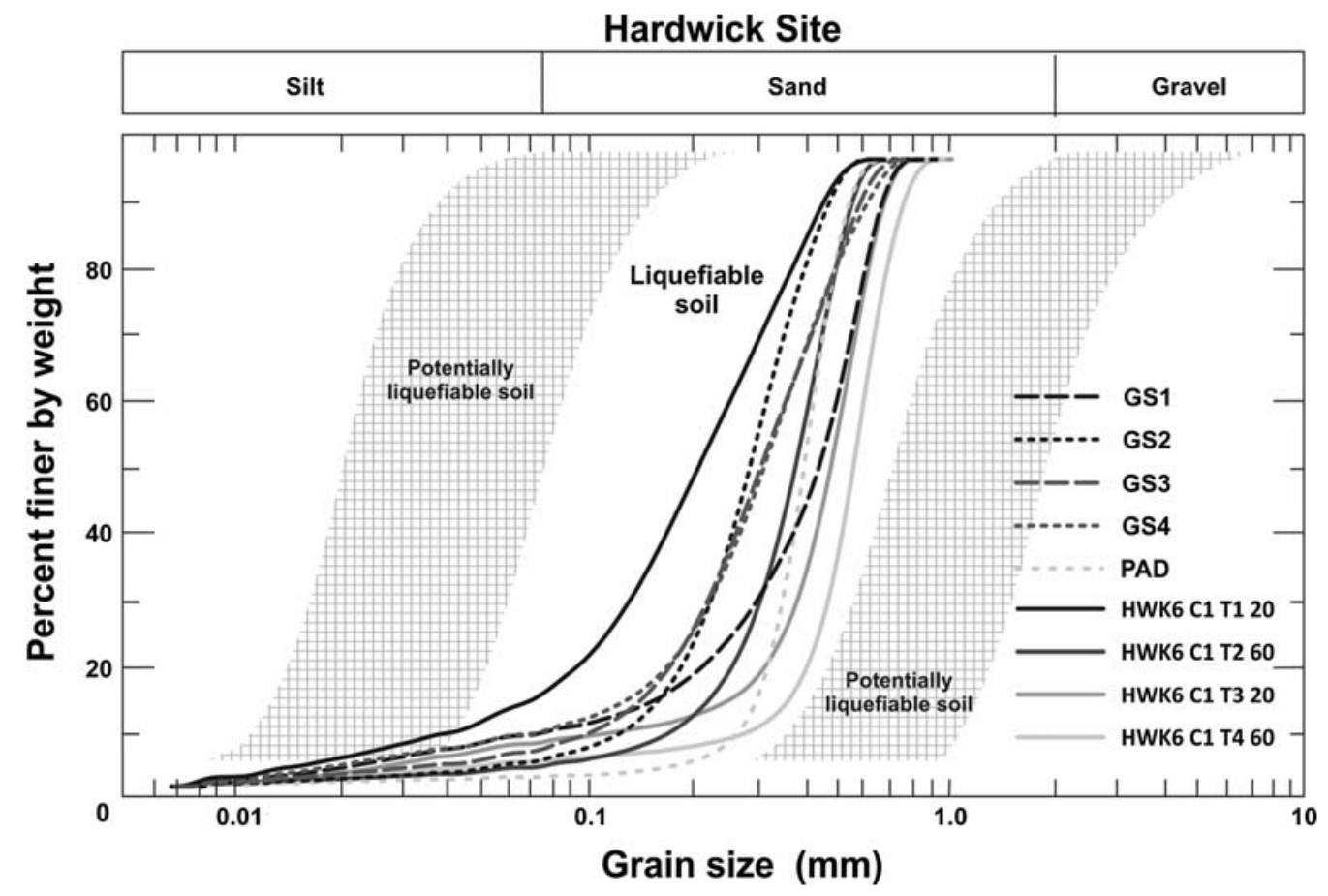

Figure 12. Comparison of particle size with thresholds for liquefiable sands based on Tsuchida (1970): GS1, paleoliquefaction dike from HWK 6 trench west wall; GS2, paleoliquefaction sand blow from HWK 6 trench east wall; GS3, modern dike from HWK 6 trench east wall; GS4 modern sand blow from HWK 6 trench east wall; PAD, nonliquefied sand from $2.8 \mathrm{~m}$ deep at HWK 4a trench; HWK 6 C1 T1 20, sand layer located at $1.8 \mathrm{~m}$ depth (core; macrounit 2); HWK 6 C1 T2 60, sand layer located at $4.0 \mathrm{~m}$ depth (core; macrounit 2); HWK 6 C1 T3 20, sand layer located at $4.8 \mathrm{~m}$ depth (core; macrounit 2); HWK 6 C1 T4 60, sand layer located at 5.5 depth (core; macrounit 3). Particle-size analysis was undertaken with a Micrometrics Saturn DigiSizer II 5205 at University of Canterbury.

coarse-grained deposits (Tuttle and Barstow, 1996). However, at the Hardwick site, based on the surface expression of liquefaction, liquefaction features not only formed along the margin of the old channel, but they also formed within the abandoned channel itself and its buried scroll bars.

The other peculiarity of the Hardwick site is that, while the meander channel and associated scroll bars extend farther south from the site (Fig. 2), the surface expression of liquefaction is prominent where the meander is covered by silt and very fine sand of the crevasse splay (macrounit 1) but is almost absent farther south. The reason for the presence of pervasive liquefaction in the area of the crevasse splay and not to the south remains unclear. The spatial association between liquefaction and the crevasse splay may be purely coincidental, but further studies are being undertaken to understand why this area was so susceptible to liquefaction.

Association between the Floodplain and Liquefaction. Particle-size analysis suggests that the sands in the floodplains are potentially liquefiable. However, no surface expression of liquefaction occurred on the floodplain. Sand samples obtained at $2.8 \mathrm{~m}$ depth from the HWK 4a trench (sample PAD in Fig. 12; trench location in Fig. 3) show a similar particle-size distribution to the liquefied sand in HWK 6 (samples GS1-GS4 in Fig. 12; location of samples on trench logs in (E) Figs. S10 and S19), and the water table was close to the surface. This observation suggests that the flood- plain could have potentially liquefied but that sand was not ejected to the surface or that the floodplain did not liquefy. Further studies with exploration methods that allow retrieval of information in water logged areas are needed to better understand the liquefaction process in the floodplain.

Inferences for Paleoseismology and Hazard Assessment from Observed Liquefaction Features. In this section, we summarize the types of liquefaction features found in the trenches and present some insights into how these observations can be used for interpretation of similar paleoliquefaction features. We also discuss the sizes of the liquefaction features in the context of earthquake magnitudes.

Types of Liquefaction Features Observed. Four main types of features have been found in the trenches in the Lincoln area:

- Sand blows that formed single and multiple, coalescing sand blows along linear fissures (e.g., Fig. 4): Some sand blows contain different types of sand (Fig. 4c), which may imply that they come from different sources during the same shaking event.

- Blisters or injections of subhorizontal dikes into the topsoil that have not fully ejected to the surface: These injections raise the ground surface, producing a subround mound, like a blister (trenches HWK 4b and MAR 4; e.g., Fig. 11). 
Occasionally, part of the injection reaches the surface via rupture of the blister.

- Dikes originating in the subsurface layers that liquefied, crosscutting overlying sediment: In some cases, these are involved in the formation of blisters and sand blows (also in most trench logs; e.g., Fig. 10a,c).

- A collapse structure associated with dikes, where softsediment faults are intruded by dikes (e.g., Fig. 11a,e): This type of structure seems to form close to the river bank and thus may be associated with lateral spreading or with collapse due to consolidation and/or evacuation of an underlying liquefiable sand reservoir.

Insights into Paleoseismic Exploration Methods. The sizes of liquefaction features described here have implications for the methods that will be most useful for identifying the presence of paleoliquefaction in similar alluvial systems. For example, high-resolution geophysics may be required to image thin dikes similar to those that formed during the 2010-2011 Canterbury earthquakes, and paleoseismic excavations may be sited in crevasse splay deposits that have been shown to bury and preserve small sand blows that would not persist for long at the ground surface.

Insights into the Age of Paleoliquefaction Features. An important aspect of estimating the age of paleoliquefaction features involves precise understanding of their temporal relationship with the host sediment (Tuttle, 2001; Tuttle et al., 2002; Tuttle and Hartleb, 2012; Bastin et al., 2015). For example, the age estimate of a buried sand blow is often based on dating the overlying and underlying sediment. A tightly constrained age of the sand blow reduces the uncertainty of the age estimate. In contrast, the age estimate of a sand dike is often based on the maximum constraining date of the sediment crosscut by the dike. As a consequence, age estimates of sand dikes generally have larger uncertainties than those for sand blows. For the purpose of time assessment, blisters need to be treated with care. In this study, blisters are found in several places with thick, clay-rich topsoil or in soil with a high root density, where it is difficult for the sand to extrude to the surface. As observed for the blisters that formed during the 20102011 Canterbury earthquakes, associated sand dikes do not always extend to the ground surface. This is an important observation for paleoliquefaction studies. In cases like this, the sediments above the blister would not provide a minimum age. The age of the sand dike is younger than the soil in which it is embedded. That is, blisters should be treated as dikes or sills when assessing their timing unless the dike extended to the ground surface and vented onto the surface as a sand blow. Typical characteristics of paleoblisters (and sills) will be that they split a layer apart (usually a paleosol in the case of blisters), and thus sediments above and below are either the same or have a natural vertical continuity (e.g., a buried soil A horizon over a soil B horizon may be split by a blister or sill). The thick dikes and sills associated with the blister present flow structures similar to dikes (e.g., thin fine-grained borders, flow laminations subparallel to the walls) but will not have lowangle or cross-lamination structures that are typical of sand blows. If no erosion occurs before the blister is buried, the mound formed by the blister may be recognizable as a convexity in the buried geomorphic surface.

Also in terms of analyzing the number of paleoseismic events found in MAR 3 trench, our observations suggest that, once the 2010-2011 liquefaction dikes are weathered, they will appear visually similar to the currently weathered paleoliquefaction dikes. Degrees of weathering are used to differentiate dike generations in the central United States (Tuttle and Hartleb, 2012). To constrain uncertainties associated with different degrees of weathering, it is important to identify crosscutting relationships so as to distinguish different generations of dikes. However, it is important to note that, during the Canterbury earthquakes, many dikes intruded along pre-existing dikes (both pre-2010 dikes and also those formed in the early parts of the Canterbury sequence), and thus paleoseismic results based only on the dike presence could significantly underestimate the number of liquefaction events (Quigley et al., 2013; Bastin et al., 2015; and this study).

Insights into the Size of Paleoliquefaction Features. We compared the size of the sand blows, blisters, and dikes studied in the trenches with other sites in Christchurch and with international examples. (E) Figure S15 and (E) Table S11 show that sand-blow sizes range from 10 to $40 \mathrm{~cm}$ height and from $>2$ to $4 \mathrm{~m}$ width, and dike widths range from 1 to $3 \mathrm{~cm}$ for both our study sites. Sand-blow heights are likely to represent multiple layers resulting from the three to four events that caused liquefaction at our study sites. Although we have not been able to quantify the sizes for each of the events at our studied sites, photographic evidence after the June 2011 event shows that the width of sand blows formed during the September earthquake $\left(\mathrm{PGA}_{7.5}=0.38 \mathrm{~g}\right)$ may represent the largest widths measured here, and that the June $2011\left(\mathrm{PGA}_{7.5}=0.04 \mathrm{~g}\right)$ sand blows are about one-third to one-half of that width (e.g., Fig. 4b).

In eastern Christchurch, dikes that formed during strong shaking (PGA $>0.4 g$ ) in the 22 February 2011 Christchurch earthquake ranged up to $25 \mathrm{~cm}$ wide, both at sites underlain by highly susceptible sediments and at sites that suffered severe lateral spreading. Maximum sand-blow heights (thickness) locally exceeded $30 \mathrm{~cm}$ in eastern Christchurch (Quigley et al., 2013). Sand-blow thicknesses and dike widths do not easily correlate because other factors such as liquefaction susceptibility of sediments, depth of the water table, material properties, and the proximity of free faces that affect lateral spreading are also important. Paleoliquefaction features identified by Bastin et al. (2015) in eastern Christchurch and those recorded in this study have similar dimensions to modern liquefaction features, suggesting that susceptibility of the sediment has not changed substantially through time. Some dikes are wider when they are close to a free face, such as the edge of a river channel; for example, in Avonside (eastern Christchurch), where lateral spreading was widespread, dikes decreased in width away from the Avon River (Bastin et al., 2015). 
Sand blows that formed during the $1988 M_{\mathrm{w}} 5.9$ Saguenay, Quebec, earthquake are of a similar size to the ones described for the 2010-2011 Canterbury events (Tuttle et al., $1990,1992)$. The Saguenay sand blows generally ranged from 7.5 to $22 \mathrm{~cm}$ thick, 30 to $500 \mathrm{~cm}$ wide, and 30 to $1000 \mathrm{~cm}$ long, with associated feeder dikes ranging from 1 to $30 \mathrm{~cm}$ wide. At the liquefaction site closest to the Saguenay epicenter, the sand blow was $10 \mathrm{~cm}$ thick, $1000 \mathrm{~cm}$ wide, and $1500 \mathrm{~cm}$ long, in association with two sand dikes 2 and $50 \mathrm{~cm}$ wide. Sand dikes in the Charlevoix seismic zone, southeastern Canada, ranged from 0.5 to $15 \mathrm{~cm}$ wide (Tuttle and Atkinson, 2010). In contrast, sand blows in the New Madrid seismic zone, United States, are commonly 1-2 m thick, tens of meters wide, tens to hundreds of meters long, and associated with sand dikes tens to hundreds cm wide (Tuttle et al., 2006; Tuttle and Hartleb, 2012).

The difference in size and area of occurrence between the 2010 and 2011 liquefaction features in the Christchurch area and the New Madrid seismic zone is likely related to (1) the liquefaction susceptibility of the sediments; (2) the characteristics of the geomorphic elements (such as the size of the braided stream and meandering stream belts of the two river systems) and local topography; and (3) the characteristics of ground shaking $\left(\mathrm{PGA}_{7.5}\right.$, frequency content and shaking duration). In general, sediment is moderately dense and liquefiable in the New Madrid region (Saucier, 1994; Obermeier, 1996), whereas sediment is loose and highly liquefiable in the Christchurch region (Elder et al., 1991). The 1811-1812 New Madrid sequence included three mainshocks of $M_{\mathrm{w}} 6.8-8.0$ and one aftershock of $M_{\mathrm{w}}$ 6.3-7.2 that induced liquefaction (Tuttle and Hartleb, 2012), whereas the Canterbury earthquake sequence included one earthquake of $M_{\mathrm{w}} 7.1$ and at least seven (possibly up to 11) earthquakes of $M_{\mathrm{w}}$ 5.2-6.2 that induced liquefaction (Quigley et al., 2013; Geotechnical Extreme Events Reconnaissance [GEER], 2010). Also, the geomorphic elements in the Mississippi alluvial system are larger than those of the Waimakariri-Halswell alluvial system. For example, some point bars in the Mississippi River are several kilometers long and hundreds of meters wide, whereas the scroll bars in the Waimakariri system area are less than $1 \mathrm{~km}$ long and only a few tens of meters wide.

We have not analyzed sand blows and dike sizes from the 2010-2011 earthquake sequence to the extent where robust comparisons between the morphology of liquefaction features can be compared with earthquake shaking intensity, epicentral distance, and/or sediment type. However, from our preliminary observations, it seems that the liquefaction features in similar alluvial sedimentary environments close to the epicenters are of a similar size, or slightly larger than (Quigley et al., 2013; Bastin et al., 2015), those found at distant areas (i.e., our study area, $17 \mathrm{~km}$ away from the $2011 \mathrm{Feb}-$ ruary epicenter). This suggests that, in addition to earthquake shaking intensity and epicentral distance, the morphology of the liquefaction features is influenced by geologic, hydrologic, and geomorphic site characteristics.

Quigley et al. (2013) showed power-law empirical relationships between relative $\mathrm{PGA}_{7.5}$ and relative sand-blow thicknesses and areal extents, indicating that surface liquefaction volumes (but not feeder-dike widths) corresponded to shaking intensity at a given site. This implied that preceding liquefaction and related effects (e.g., soil densification) did not significantly reduce the susceptibility of sediments to future liquefaction at the studied site. Furthermore, only two generations of liquefaction feeder dikes were recognized at the site despite 10 or more observed liquefaction events, implying the number of distinguishable feeder-dike generations may significantly underrepresent the number of actual liquefaction episodes.

\section{Paleoliquefaction}

Age of Paleoliquefaction Features. At the Hardwick site, paleoliquefaction features formed between A.D. 908 and A.D. 1336, based on OxCal analysis of the age of sediments (older than layer $6 \mathrm{bA}$, paleosol, and younger than the base of layer $5 \mathrm{Cg}$ ) and a piece of wood found within the paleosand blow (maximum age; radiocarbon sample HWK T6-C6; Fig. 7b and (E) Fig. S22). The paleoliquefaction event occurred after the formation of the soil in the top of macrounit 2 (unit $6 \mathrm{bA}$, radiocarbon sample HWK T6-C5) and before deposition of the crevasse splay deposits of macrounit 1 (unit 5Cg; e.g., HWK 6 trench; Fig. 6b, (E) Figs. S9 and S10; radiocarbon samples HWK T6-C7, HWK T6-C10, and HWK T6-C14). The paleosand blow formed when unit 6bA (HWK 6 trench) was at the ground surface. The upper portion of the sand blow was subsequently eroded. The trees rooted in the paleosol (radiocarbon sample HWK T6-C12) died when younger fluvial sands (crevasse splay sediments) were deposited over the erosional surface

At the Marchand site, paleoliquefaction features formed between A.D. 1017 and A.D. 1840. This date is based on the age of sediments and OxCal analysis (Fig. 10a and (E) Fig. S13; OxCal analysis in (E) Fig. S23). The mottled and weathered sand dikes crosscut sediment deposited after A.D. 995-1141 (calibrated age for sample MAR T3-C1; Fig. 10). The paleodikes extend to the base of the topsoil, but there is no related sand blow to indicate ground-surface exposure at the time of the event. Therefore, we are unable to constrain the minimum age of this event. No historical earthquake is known to have induced liquefaction in this area; therefore, we assume the weathered liquefaction features probably formed before European settlement ( 1840). However, it is possible that sparse population hindered reporting of liquefaction associated with the 1870 Lake Ellesmere earthquake (see more discussion in the Correlation of Paleoliquefaction Features with Historic and Prehistoric Earthquakes section).

Number of Paleoseismic Events. The poorly constrained age estimated for the Marchand paleoliquefaction features overlap the age of the Hardwick features. Given the proximity of the two sites, the simplest interpretation is that they formed during the same event, but it is possible they formed in different events. It is also possible that the paleoliquefaction features found at the Marchand site were formed by two 
or more events, one of them being the same as that recorded at the Hardwick site. Although we do not observe any crosscutting relationships among the paleodikes mapped in the MAR 3 trench (Fig. 10a) that could be indicative of more than one event, it is still possible that several intrusions occurred along the same dike paths and removed evidence of preceding events. It is also possible that mottling hinders discrimination between events (Quigley et al., 2013, reported several surface liquefaction extrusions associated with the Canterbury sequence with feeder dikes that contained evidence for only one intrusion event).

We do not have a clear stratigraphic link to confirm that the paleoliquefaction at the Hardwick and Marchand sites represents the same shaking event. Nor do we have any evidence to support more than one paleoliquefaction event. If we assume that the paleoliquefaction recorded at the two sites is from the same event, which is plausible given the close proximity $(2 \mathrm{~km})$ and the similar responses during the 2010-2011 liquefaction events, then the timing of the paleoevent would be the intersection of the age estimates of paleoliquefaction features at each site (or A.D. 1019-1337; OxCal analysis in (E) Fig. S24). In summary, and with the data available, we conclude that at least one liquefaction event occurred in the Lincoln area between A.D. 908 and A.D. 1336 (from Hardwick data) or A.D. 10191337 (assuming the Hardwick and Marchand events are the same), although we cannot rule out the occurrence of another event in the period A.D. 1017-1840 or even younger (i.e., the 1870 Lake Ellesmere event, see discussion in the next section).

Correlation of Paleoliquefaction Features with Historic and Prehistoric Earthquakes. In Figure 13, we plot the timing of paleoliquefaction at our sites, along with the timing of known historic and prehistoric earthquakes in the wider region, in relation to their epicentral distance to our sites. We also identify other active faults that are close to the site but for which we do not have a seismic record (Forsyth et al., 2008; Stirling et al., 2012; see also Fig. 1 for fault locations).

As a first approximation to excluding some of these seismic-source candidates, we used a $\mathrm{PGA}_{7.5}$ threshold approach (e.g., Quigley et al., 2013; Santucci de Magistris et al., 2013) and the new magnitude-bound relations developed from historic New Zealand liquefaction data (Maurer et al., 2015). For the $\mathrm{PGA}_{7.5}$ threshold approach, we used two different ground-motion prediction equations (GMPEs, McVerry et al., 2006; Bradley, 2013) to calculate the $\mathrm{PGA}_{7.5}$ (magnitude weighted; Youd et al., 2001) at our site from modeled ruptures of each fault (Table 1). Thresholds for inducing liquefaction have been suggested from $\mathrm{PGA}_{7.5}=0.09 \mathrm{~g}$ from an international database (Santucci de Magistris et al., 2013) or as low as $\mathrm{PGA}_{7.5}=0.06 \mathrm{~g}$ for a highly susceptible area of Christchurch (Quigley et al., 2013).

We note that using the $\mathrm{PGA}_{7.5}$ threshold concept does not include important information on the mechanics of liquefiable soils. For example, we are not accounting for frequency effects of the motions and changes in shear strength of the soil column (e.g., Seed and Idriss, 1971; Idriss and Boulanger, 2008).
Therefore, results based on this approach are only preliminary. However, given that there is a rich set of recorded PGA data close to our site, we consider that using this approach in conjunction with Maurer et al. (2015) may bring some more insights into what earthquake sources could have produced paleoliquefaction at Lincoln. To assess the threshold PGA $_{7.5}$ at which liquefaction may occur at our study site, we used the Canterbury records at the nearby LINC seismic station ( $\sim 3 \mathrm{~km}$ away from the site), which is located on similar soil (type D soil of the New Zealand Standard NZS1170, 2004), and information on historic earthquakes. For these historic earthquakes, we either know or can calculate the $\mathrm{PGA}_{7.5}$ and have records to determine whether they historically caused liquefaction or not. During the Canterbury earthquake sequence, the 4 September $2010\left(M_{\mathrm{w}} 7.1\right)$, the 22 February 2011 $\left(M_{\mathrm{w}} 6.2\right)$, and the 13 June $2011\left(M_{\mathrm{w}} 6.0\right)$ liquefaction occurred at the two sites. Landowners of both properties reported a much larger degree of liquefaction during the September 2010 event than the June 2011 event. When asked to rate the proportions of liquefaction for different events, the landowners rated them in the following way: if September 2010 is considered 100\%, February would be $80 \%$ and $60 \%$, and June would be $15 \%$ and $<1 \%$ for the Hardwick and Marchand sites, respectively. There are no historical reports of liquefaction in Lincoln during the 1869 Christchurch earthquake $\left(M_{\mathrm{w}} 4.7-4.8\right)$, the 1870 Lake Ellesmere earthquake ( $M_{\mathrm{w}}$ 5.6-5.8) (Downes and Yetton, 2012), or the 1888 Amuri earthquake (Hutton, 1888).

The magnitude-weighted PGAs recorded at LINC station during the Canterbury earthquake sequence are plotted against $M_{\mathrm{w}}$ in Figure 14 and events that produced liquefaction are highlighted. We also highlighted one aftershock of 4 September 2010 event, $20 \mathrm{~min}$ after the main event, that could have caused liquefaction (identified as "possible liquefaction" in Fig. 14), but this would not have been distinguishable from the mainshock because both events occurred during the night. The plot shows that the liquefaction triggering threshold for widespread liquefaction is at least as low as $\mathrm{PGA}_{7.5}=0.07 \mathrm{~g}$ at this site from the occurrence of liquefaction associated with the $22 \mathrm{Feb}-$ ruary 2011 event. It is also possible that smaller events, such as on 13 June $2011\left(\mathrm{PGA}_{7.5}=0.04 \mathrm{~g}\right)$, can also cause minor liquefaction, but there were several events with similarly low $\mathrm{PGA}_{7.5}$ that did not produce liquefaction.

Comparisons of the threshold suggested here for triggering widespread liquefaction $\left(\mathrm{PGA}_{7.5}=0.07 \mathrm{~g}\right.$ ) with the $\mathrm{PGA}_{7.5}$ calculated at the site from rupture of regional faults can be used as a preliminary approach to help assess which faults could produce substantial liquefaction at Lincoln. Table 1 shows that regional faults that are more than $100 \mathrm{~km}$ away from Lincoln could cause only minor liquefaction there (except for the Alpine fault). However, all regional faults within $<60 \mathrm{~km}$ (Table 1) could cause widespread liquefaction.

The probabilities of liquefaction at Lincoln for various seismic sources based on the magnitude-bound relations developed by Maurer et al. (2015) are shown in Table 1 . These results suggest high probabilities (16\%-93\% and $31 \%$, respectively) that sources within a $60 \mathrm{~km}$ radius of 


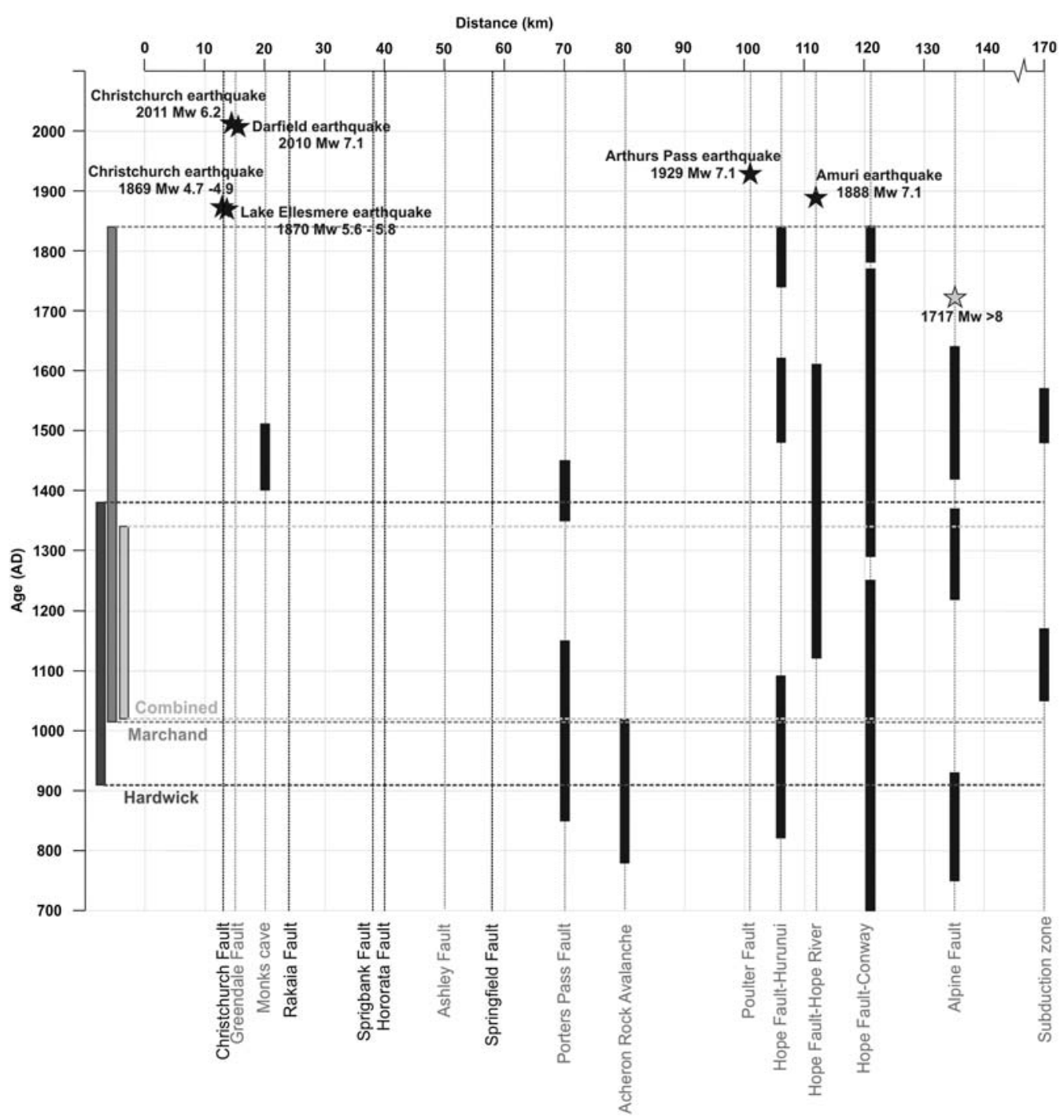

Figure 13. Timing of major historic earthquakes, prehistoric fault ruptures, and large landslides in the wider region. Timing information from subduction zone, Clark et al. (2015); Alpine fault, Berryman et al. (1992), Berryman, Cochran, et al. (2012), Berryman, Cooper, et al. (2012), and Howarth et al. (2012, 2014); Hope fault, Conway segment, Langridge et al. (2003); Hope fault, Hope River segment, Cowan and McGlone (1991); Hope fault, Hurunui segment, Langridge et al. (2013) and Khajavi et al. (see Data and Resources); Poulter fault, Berryman and Villamor (2004); Acheron rock avalanche, Smith et al. (2006); Porters Pass fault, Howard et al. (2005); Ashley fault, Sisson et al. (2001); Moncks Cave, Jacomb (2008, 2009). Location information for all faults from Litchfield et al. (2014) and references therein. Vertical black dotted lines associated with individual faults indicate that there are no paleoearthquake data. Vertical gray dotted lines indicate that paleoearthquake studies suggest that no ruptures occurred for that fault during that period.

Lincoln as well as the much more distant $(135 \mathrm{~km})$ Alpine fault can produce extensive liquefaction. Maurer et al. (2015) show similar results for a site in eastern Christchurch.

Although there is no historic record of liquefaction during the 1869 Christchurch and the 1870 Lake Ellesmere earthquakes at Lincoln, we interpret this as "absence of evidence" rather than "evidence of absence": the sparse population and the likelihood of incomplete reporting dictate a conservative approach.

Figure 14 and Table 1 can also help to assess this question. We calculated the possible PGA $_{7.5}$ and the probabilities of liquefaction (from Maurer et al., 2015) for these two events using the mean distance and $M_{\mathrm{w}}$ values (there is great uncertainty in these two parameters). Our calculations sug- gest that it is highly likely that the 1870 Lake Ellesmere event produced liquefaction at Lincoln. However, PGA 7.5 values for the 1869 Christchurch earthquake suggest that it could have triggered only minor liquefaction, if any.

Fault Sources Associated with Paleoliquefaction Features. The simplest interpretation of the paleoliquefaction features at the Hardwick and Marchand sites is that they formed as the result of the same event (A.D. 1019-1337). It is known from other paleoseismic studies that several faults ruptured during the same period as the paleoliquefaction event. These faults include the subduction zone (southern segment), the Alpine fault, the Hope fault (Conway, Hope River, and Hurunui segments), and the Porters Pass fault (see the Fig. 13 caption for 


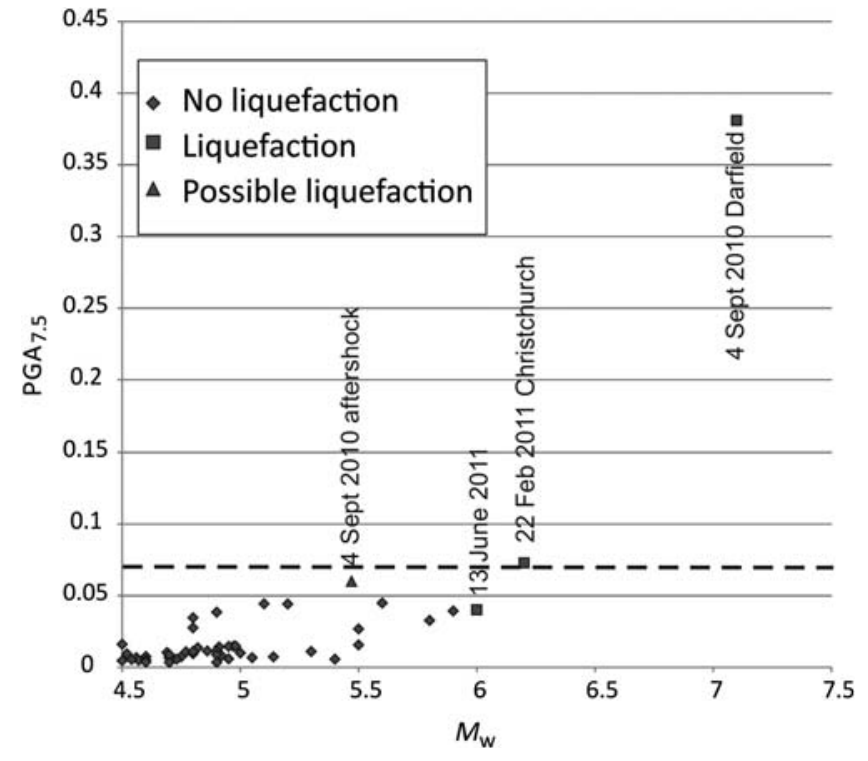

Figure 14. Peak ground acceleration (PGA) normalized to $M_{\mathrm{w}} 7.5\left(\mathrm{PGA}_{7.5}\right)$ versus $M_{\mathrm{w}}$ and approximate liquefaction-triggering threshold for $M_{\mathrm{w}} \geq 4.5$ for widespread liquefaction $\left(\mathrm{PGA}_{7.5} \geq 0.07 \mathrm{~g}\right.$; dashed line). Minor liquefaction occurred during the 13 June 2011 event with $\mathrm{PGA}_{7.5} \sim 0.04 g$.

references). Using $\mathrm{PGA}_{7.5} \geq 0.07 g$ as a possible liquefaction threshold and the magnitude-bound relations for paleoliquefaction analysis from Maurer et al. (2015), we further limit these sources to the Porters Pass fault about $70 \mathrm{~km}$ distance (penultimate event; $50 \%$ probability) and the Alpine fault at $135 \mathrm{~km}$ distance (penultimate event; $35 \%$ probability). Rupture of the Porters Pass fault is known to have caused a large rock avalanche in the southern Alps (Smith et al., 2006). Other faults close to Lincoln (Hororata, Springbank, and Rakaia), for which there are no paleoearthquake data, also could have produced liquefaction at our site PGA $_{7.5}$ at Lincoln $>0.09 g$; and $50 \%-84 \%$ probability based on Maurer et al., 2015).

Although the Hope fault produced paleoearthquakes during this time period, these have not been considered, because the potential median PGA $_{7.5}$ at Lincoln from this fault is below the threshold and Maurer et al. (2015) suggest a <7\% probability. However, better constraints on shaking thresholds for the area or a more in-depth analysis of the soil properties at Lincoln and other sites could increase our confidence in this initial finding. The Greendale fault has also been excluded, because its penultimate event is likely to have occurred $>20,000$ years ago (Villamor et al., 2012; Hornblow et al., 2014). In addition, the Ashley fault has not ruptured in the last 1300 years and has similarly been discounted (Sisson et al., 2001).

If the paleoliquefaction at the Marchand site occurred after that at the Hardwick site, several fault sources that ruptured during the period A.D. 1340-1840 could have been responsible (Table 1 and Fig. 13). The Porters Pass fault (most recent event), the Alpine fault (either of the last two events), the subduction zone (earthquake 1 of Clark et al., 2015, which could be a multiple segment rupture), or any of the faults with no earthquake record (Hororata, Springbank, Ashley, and
Rakaia) are potential candidates. The Porters Pass fault is a strong candidate because the timing of its most recent event may coincide with dates for the sealing of Moncks Cave in Sumner, Christchurch, by a rock avalanche (Jacomb, 2008; 2009). Although it is possible that this failure was not seismically triggered, the location of the avalanche is only $22 \mathrm{~km}$ away from the Marchand site (and at a similar distance from the fault source as the Marchand site), which could indicate that both sites experienced strong shaking simultaneously.

The age estimate of a major paleoearthquake(s) presented here is only preliminary. Dating of more paleoliquefaction features at additional sites across the Canterbury area would greatly improve our determination of the timing and the likely seismic source. Furthermore, several active faults, closer to the site than those discussed above and for which there currently are no paleoearthquake data, could have been responsible for the paleoliquefaction described herein. In addition, given that 10 of the 11 liquefaction-inducing earthquakes in the Christchurch area during the 2010-2011 sequence were produced by blind faults, there is a strong possibility that the paleoliquefaction events presented were also triggered by proximal blindfault earthquakes. For example, Bastin et al. (2015) tentatively attributed some of the pre-2010 liquefaction features in eastern Christchurch to the $1869 M_{\mathrm{w}} 4.9$ Christchurch earthquake. Recently, identified offshore active faults (Barnes et al., 2011) provide additional seismic sources to consider. If paleoliquefaction on the southeastern Canterbury Plains is related to local earthquakes, the timing of paleoliquefaction events can fill an important gap in the paleoearthquake record for the Christchurch region. It is also important to note that the lack of paleoliquefaction features in a particular trench does not indicate that certain faults did not cause liquefaction in our study area; it may indicate that we have not exposed it in our trenches. However, the predilection for liquefaction sites to reliquefy during subsequent events and for injections to reuse preexisting dikes gives us more confidence that our record is not strongly biased by lack of discovery. Importantly, identification and dating of paleoliquefaction features in the wider area that can be influenced by shaking caused by rupture of the subduction zone could contribute to understanding the impacts and timing of this type of rupture.

Paleoliquefaction studies, along with analysis of $\mathrm{PGA}_{\mathrm{s}}$ recorded during the Canterbury earthquake sequence (or any other recent earthquakes that may or may not have caused liquefaction at a study site), can better constrain potential PGA $_{7.5}$ thresholds and can be combined with additional fault paleoseismic studies (e.g., Hornblow et al., 2014) and other geologic indicators of strong shaking (e.g., Mackey and Quigley, 2014) to inform the paleoearthquake history for the region.

\section{Conclusions}

We documented liquefaction features at two sites (Hardwick and Marchand sites) in Lincoln (southwest of Christchurch) that formed during the 2010-2011 Canterbury earthquake sequence. Paleoliquefaction features were also 
identified at both sites. Comparison of detailed geomorphic mapping (assisted by high-resolution DEMs) with the spatial distribution of liquefaction features, and with information on the potential sand source for the liquefied sand from trenches and cores, suggests a strong correlation between liquefaction and alluvial channel and point-bar deposits. This is clearly displayed at the Marchand site, located at the inner meander bend of the Halswell River, and at other similar sites along this river course. At the Hardwick site, located at an abandoned meander channel close to the Halswell River, this association is to some extent obscured by the burial of the meander channel and its scroll bar complex by a crevasse splay. Nevertheless, preliminary analysis of trenched sediments and surface liquefaction patterns suggests an association between surface expression of liquefaction and the margins and the inner part of the meander bend of the abandoned channel and with its associated scroll bar complex. In addition, this study shows how detailed geomorphic studies can be used to identify areas of potential paleoliquefaction for further investigation.

Documentation of the type and size of the 2010-2011 liquefaction features and their relationship with the hosting sediment provides insights into analysis of paleoliquefaction features in areas with sedimentary environments similar to the Canterbury Plains. The modern features include single and multiple coalescing sand blows along linear fissures; blisters, which are mounded soils above injections of sills, and shallowly dipping dikes into the topsoil; dikes, some of which are related to the blows and blisters; and collapse structures related to ground failure. The sizes of the preserved features (e.g., dikes tend to be around $2-5 \mathrm{~cm}$ thick) may not only be associated with the specific strong-ground-shaking level at the site, but can also be limited by the size of the features with the sedimentary environment (e.g., size of a scroll bar). Because small sand blows may not persist for long at the ground surface, it is critical to site paleoseismic trenches in settings of sediment accumulation where sand blows may be buried and preserved by subsequent deposits (e.g., crevasse splay covering the abandoned meander deposit). Our results also show that, when analyzing paleoliquefaction features, it is important to recognize the thick sills and dikes below blisters as intrusions (in contrast to sand blows or extrusions) so that interpretation of the age of the intrusions is accurate (i.e., the age of the layer above a sill does not constrain the youngest age of the sill).

Finally, we estimated the age of the paleoliquefaction features at both sites and compared them with the ages of documented paleoearthquakes from known fault sources. We also analyzed the potential of other sources (with no paleoseismic data) to induce liquefaction at our sites using the New Zealand GMPEs and assessed a preliminary liquefaction-triggering $\mathrm{PGA}_{7.5}$ at our sites using the seismic records of the Canterbury earthquake sequence. We obtain a threshold $\mathrm{PGA}_{7.5}$ of $\sim 0.07 \mathrm{~g}$, similar to other sites in Christchurch. We used that threshold and existing magnitude-bound relations to identify potential fault sources for the paleoliquefaction features found at Lincoln. Although this preliminary study has not provided sufficient data to confirm the earthquake source, a number of po- tential candidates have been proposed that could form the basis of further investigation. One interpretation is that paleoliquefaction at both sites resulted from the same strong-ground-shaking event with an age of A.D. 1019-1337, based on dating of host sediments. It seems that most of the known regional sources within a radius of $100 \mathrm{~km}$, and perhaps marginally distant large faults such as the Alpine fault and the subduction zone, could produce liquefaction in Lincoln, based on $\mathrm{PGA}_{7.5}$ estimates and magnitude-bound relations. Known paleoearthquakes that could be responsible for the strong ground shaking at the time of the paleoliquefaction event in Lincoln include the penultimate event on the Porter Pass fault or the Alpine fault. The Greendale and Ashley faults were unlikely sources because they did not rupture at that time. A second interpretation is that there is an additional, more recent, paleoliquefaction event at A.D. 1340-1840 (or -1870) that is represented at the Marchand site. Such an event could have been caused by ruptures of the Porters Pass fault, Alpine fault, and subduction zone (large rupture).

The Canterbury earthquake sequence has provided invaluable information to gain further insights into the liquefaction process and seismic hazard in regions of low-tomoderate seismicity. Results from two sites, such as this study, are preliminary in terms of estimating the timing and identifying sources of prehistoric earthquakes. However, we presented a powerful approach that will provide conclusive results with the study of additional sites across the region, through the combined analysis of recorded PGAs; magnitudebound relations for paleoliquefaction analysis; presence or absence of liquefaction for different PGA thresholds; and the identification and dating of paleoliquefaction events at the same site. Moreover, understanding local liquefactiontriggering thresholds over a wider area will greatly improve knowledge of the impacts of earthquakes produced by large interplate faults (e.g., Alpine fault and the subduction zone in New Zealand) and could greatly improve the understanding of the potential magnitudes of these events.

\section{Data and Resources}

The peak ground acceleration records used in this study are from Geonet, New Zealand (info.geonet.org.nz/display/ appdata/Strong-Motion+Data, last accessed January 2015). Active fault data are from the GNS Science Active Fault database (http://data.gns.cri.nz/af/, last accessed August 2014). Pre-2010 aerial photos stereo pairs with a 1:16,000 scale and were taken in the 1940s and 1960s; GNS collection, also accessible at http://photosales.opus.co.nz/about/history.htm (last accessed February 2015). Modern orthophotos are from Land Information New Zealand (LINZ) (http://www.linz. govt.nz/land/maps/aerial-imagery-and-orthography, last accessed January 2014). Google Earth Maps are online at https://www.google.com/earth (last accessed January 2014). The digital elevation model from light detection and ranging (lidar) survey from Canterbury Geotechnical Database, supplied by Canterbury Regional Council (https://www.nzgd.org.nz/, last accessed January 2013). N. Khajavi, R. M. Langridge, 
M. C. Quigley, C. Smart, A. Rezanejad, and F. Martin-Gonzalez, Late Holocene rupture overlap and earthquake clustering on the Hope fault, New Zealand, is under review with the Geological Society of America Bulletin. All other data used in this article came from the published sources listed in the references.

\section{Acknowledgments}

We thank the Hardwick and Marchand families for land access. Caroline Hardwick provided invaluable information, including an extensive photographic record of the liquefaction events. Canterbury Regional Council (ECAN) acquired light detection and ranging (lidar) and aerial photography and made it available for research purposes. Numerous colleagues from the University of Canterbury, Lincoln University, and University of Madrid assisted with fieldwork and discussions. Bella Ansell and Kathleen Turner assisted with GIS work. Mark Stirling, Graeme McVerry, and Chris Van Houtte helped with peak ground acceleration calculations. Radiocarbon ages were provided by Rafter Radiocarbon Laboratory, GNS Science. Dougal Townsend and Jon Carey provided GNS Science internal reviews. Two anonymous reviewers and Associate Editor Yann Klinger provided constructive reviews that greatly improved this article. This study is funded by the New Zealand Earthquake Commission, the New Zealand National Hazards Platform, and GNS Development and Core funds.

\section{References}

Almond, P., P. Villamor, M. Tuttle, R. Langridge, K. Clark, A. Eger, S. Bastin, M. Quigley, P. Barker, and M. Vandergoes (2012). Liquefaction induced by the 2010-2011 Canterbury earthquake sequence and implications of recently discovered paleoliquefaction features, Geol. Soc. Am. Abstr. Progr. 44, no. 7, 414.

Bannister, S., and K. Gledhill (2012). Evolution of the 2010-2012 Canterbury earthquake sequence, New Zeal. J. Geol. Geophys. 55, no. 3, 295-304.

Barnes, P. M., C. Castellazzi, A. Gorman, and S. Wilcox (2011). Submarine faulting beneath Pegasus Bay, offshore Christchurch. Short-term Canterbury Earthquake Recovery Project 2: Offshore faults, National Institute of Water \& Atmosphere (NIWA) Client Report WLG2011-28, 46 pp.

Bastin, S., M. Quigley, K. Bassett, and R. A. Green (2013). Modern and paleo-liquefaction features in eastern Christchurch and strategies for locating pre-historic liquefaction, C. Y. Chin (Editor), Proc. 19th NZGS Geotechnical Symposium, Queenstown, New Zealand, 9-12 November 2013, 8 pp.

Bastin, S. H., K. Bassett, M. Quigley, B. Maurer, R. A. Green, B. Bradley, and D. Jacobson (2016). Late Holocene liquefaction at sites of contemporary liquefaction during the 2010-2011 Canterbury earthquake sequence, New Zealand, Bull. Seismol. Soc. Am. 106, no. 3, doi: 10.1785/0120150166.

Bastin, S. H., M. Quigley, and K. Bassett (2015). Paleoliquefaction in Christchurch, New Zealand, Geol. Soc. Am. Bull. 127, nos. 9/10, 1348-1365, doi: 10.1130/B31174.1.

Beavan, J., S. Ellis, L. Wallace, and P. Denys (2007). Kinematic constraints from GPS on oblique convergence of the Pacific and Australian plates, central South Island, New Zealand, in A Continental Plate Boundary: Tectonics at South Island, New Zealand, D. Okaya, T. Stern, and F. Davey (Editors), American Geophysical Union, Washington, D. C., 75-94, doi: 10.1029/175GM05.

Beavan, J., M. Motagh, E. J. Fielding, N. Donnelly, and D. Collett (2012). Fault slip models of the 2010-2011 Canterbury, New Zealand, earthquakes from geodetic data and observations of postseismic ground deformation, New Zeal. J. Geol. Geophys. 55, no. 3, 207-221.

Berrill, J. B., P. C. Mulqueen, and E. T. C. Ooi (1994). Liquefaction at Kaiapoi in the 1901 Cheviot, New Zealand, earthquake, Bull. New Zeal. Natl. Soc. Earthq. Eng. 27, no. 3, 178-190.

Berryman, K. (2012). Geoscience as a component of response and recovery from the Canterbury earthquake sequence of 2010-2011, New Zeal. J. Geol. Geophys. 55, no. 3, 313-319.
Berryman, K., and P. Villamor (2004). Surface rupture of the Poulter fault in the 1929 March 9 Arthur's Pass earthquake, and redefinition of the Kakapo fault, New Zealand, New Zeal. J. Geol. Geophys. 47, no. 2, 341-351.

Berryman, K., U. Cochran, K. Clark, G. Biasi, R. Langridge, and P. Villamor (2012). Major earthquakes occur regularly on an isolated plate boundary fault, Science 336, 1690-1693, doi: 10.1126/science.1218959.

Berryman, K., A. Cooper, R. Norris, P. Villamor, R. Sutherland, T. Wright, E. Schermer, R. Langridge, and G. Biasi (2012). Late Holocene rupture history of the Alpine fault in south Westland, New Zealand, Bull. Seismol. Soc. Am. 102, no. 2, 620-638.

Berryman, K. R., S. Beanland, A. F. Cooper, H. N. Cutten, R. J. Norris, and P. R. Wood (1992). The Alpine fault, New Zealand: Variation in Quaternary structural style and geomorphic expression, Ann. Tecton. 6, 126-163.

Brackley, H. (compiler) (2012). Review of liquefaction hazard information in eastern Canterbury, including Christchurch City and parts of Selwyn, Waimakariri and Hurunui Districts, 2012 ECA Report, R12/83, 99 pp.

Bradley, B. A. (2013). A New Zealand-specific pseudo-spectral acceleration ground-motion prediction equation for active shallow crustal earthquakes based on foreign models, Bull. Seismol. Soc. Am. 103, no. 3, 1801-1822.

Bronk Ramsey, C. (2009). Bayesian analysis of radiocarbon dates, Radiocarbon 51, no. 1, 337-360.

Brown, L. J., and J. H. Weeber (1992). Geology of the Christchurch urban area: Institute of Geological and Nuclear Sciences Geological Map 1, Institute of Geological and Nuclear Sciences Limited, Lower Hutt, New Zealand, scale 1:25,000.

Brown, L. J., D. D. Wilson, N. T. Moar, and D. C. Mildenhall (1988). Stratigraphy of late Quaternary deposits of the northern Canterbury Plains, New Zealand, New Zeal. J. Geol. Geophys. 31, no. 3, 305-335.

Browne, G. H., and T. R. Naish (2003). Facies development and sequence architecture of a late Quaternary fluvial-marine transition, Canterbury Plains and shelf, New Zealand: Implications for forced regressive deposits, Sediment. Geol. no. 158, 57-86.

Campbell, J. K., J. R. Pettinga, and R. Jongnes (2012). The tectonic and structural setting of the 4 September 2010 Darfield (Canterbury) earthquake sequence, New Zealand, New Zeal. J. Geol. Geophys. 55, no. 3, 155-168.

Civico, R., C. A. Brunori, P. M. De Martini, S. Pucci, F. R. Cinti, and D. Pantosti (2015). Liquefaction susceptibility assessment in fluvial plains using airborne lidar: The case of the 2012 Emilia earthquake sequence area (Italy), Nat. Haz. Earth Syst. Sci. no. 15, 2473-2483, doi: 10.5194/nhess-15-2473-2015.

Clark, K. J., B. W. Hayward, U. A. Cochran, L. M. Wallace, W. L. Power, and A. T. Sabaa (2015). Evidence for past subduction earthquakes at a plate boundary with widespread upper plate faulting: Southern Hikurangi margin, New Zealand, Bull. Seismol. Soc. Am. 105, no. 3, doi: 10.1785/0120140291.

Cowan, H. A., and M. S. McGlone (1991). Late Holocene displacements and characteristic earthquakes on the Hope River segment of the Hope fault, New Zealand, J. Roy. Soc. New Zeal. 21, no. 4, 373-384.

Cox, S. C., H. K. Rutter, A. Sims, M. Manga, J. J. Weir, T. Ezzy, P. A. White, T. W. Horton, and D. Scott (2012). Hydrological effects of the $M_{\mathrm{w}} 7.1$ Darfield (Canterbury) earthquake, 4 September 2010, New Zealand, New Zeal. J. Geol. Geophys. 55, no. 3, 231-247.

Cubrinovski, M., and R. A. Green (Editors) (2010). Geotechnical reconnaissance of the 2010 Darfield (Canterbury) earthquake (contributing authors: Allen, J., S. Ashford, E. Bowman, B. Bradley, B. Cox, M. Cubrinovski, R. Green, T. Hutchinson, E. Kavazanjian, R. Orense, M. Pender, M. Quigley, and L. Wotherspoon) (Special Issue), Bull. New Zeal. Soc. Earthq. Eng. 43, no. 4, 243-320.

Cubrinovski, M., J. D. Bray, M. Taylor, S. Giorgini, B. Bradley, L. Wotherspoon, and J. Zupan (2011). Soil liquefaction effects in the central business district during the February 2011 Christchurch Earthquake, Seismol. Res. Lett. 82, no. 6, 893-904.

Downes, G., and M. Yetton (2012). Pre-2010 historical seismicity near Christchurch, New Zealand: The $1869 M_{\mathrm{w}}$ 4.7-4.9 Christchurch and $1870 M_{\mathrm{w}}$ 5.6-5.8 Lake Ellesmere earthquakes, New Zeal. J. Geol. Geophys. 55, no. 3, 199-205. 
Elder, D. M., I. F. McCahon, and M. D. Yetton (1991). The Earthquake Hazard in Christchurch: A Detailed Evaluation, Research Report to the $E Q C$, Soils and Foundations Ltd., Christchurch, New Zealand, 80 pp.

Field, B. D., G. H. Brown, B. W. Davy, R. H. Herzer, R. H. Hoskins, J. I. Raine, G. J. Wilson, R. J. Sewell, D. Smale, and W. A. Watters (1989). Cretaceous and Cenozoic sedimentary basins and geological evolution of the Canterbury region, South Island, New Zealand, New Zealand Geological Survey Basin Studies 2, Department of Scientific and Industrial Research, Wellington, New Zealand, 94 pp. + enclosures.

Forsyth, P. J., R. Jongens, and D. J. A. Barrell (2008). Geology of the Christchurch area. Geological Map 16, GNS Science, Lower Hutt, New Zealand, scale $1: 250,000,1$ sheet +67 pp.

Geotechnical Extreme Events Reconnaissance (GEER) (2010). Geotechnical reconnaissance of the 2010 Darfield (New Zealand) Earthquake, version 1: November 14, 2010, Report of the National Science Foundation-Sponsored Geotechnical Extreme Events Reconnaissance (GEER) Team. GEER Association Report No. GEER-024, http://www.geerassociation. org/administrator/components/com_geer_reports/geerfiles/GEER_ Darfield_2010_11-14-2010.pdf (last accessed August 2015).

Hogg, A. G., Q. Hua, P. G. Blackwell, M. Niu, C. E. Buck, T. P. Guilderson, T. J. Heaton, J. G. Palmer, P. J. Reimer, R. W. Reimer, et al. (2013). SHCal13 southern hemisphere calibration, 0-50, 000 cal yr BP, Radiocarbon 55, no. 4, doi: 10.2458/azu_js_rc.55.16783.

Holden, C. (2011). Kinematic source model of the 22 February $2011 M_{\mathrm{w}} 6.2$ Christchurch earthquake using strong motion data, Seismol. Res. Lett. 82, no. 6, 783-788.

Holzer, T. L., T. E. Noce, and M. J. Bennett (2011). Liquefaction probability curves for surficial geologic deposits, Environ. Eng. Geosci. 17, no. 1, $1-21$.

Hornblow, S., M. Quigley, A. Nicol, R. Van Dissen, and N. Wang (2014) Paleoseismology of the $2010 M_{\mathrm{w}} 7.1$ Darfield (Canterbury) earthquake source, Greendale fault, New Zealand, Tectonophysics 637, 178-190.

Howard, M., A. Nicol, J. Campbell, and J. R. Pettinga (2005). Holocene paleoearthquakes on the strike-slip Porters Pass fault, Canterbury, New Zealand, New Zeal. J. Geol. Geophys. 48, no. 1, 59-74.

Howarth, J. D., S. J. Fitzsimons, R. J. Norris, and G. E. Jacobsen (2012). Lake sediments record cycles of sediment flux driven by large earthquakes on the Alpine fault, New Zealand, Geology 40, no. 12, 1091-1094.

Howarth, J. D., S. J. Fitzsimons, R. J. Norris, and G. E. Jacobsen (2014). Lake sediments record high intensity shaking that provides insight into the location and rupture length of large earthquakes on the Alpine fault, New Zealand, Earth Planet. Sci. Lett. 403, 340-351.

Hughes, M., M. Quigley, S. van Ballegooy, B. Deam, B. Bradley, D. Hart, and R. Measures (2015). The sinking city: Earthquakes increase flood hazard in Christchurch, New Zealand, GSA Today 25, no. 3, 4-10.

Hutton, F. W. (1988). The earthquake in the Amuri, Trans. New Zeal. Inst. 21, 269-293.

Idriss, I. M., and R. W. Boulanger (2008). Soil liquefaction during earthquakes, Monograph MNO-12, Earthquake Engineering Research Institute, Oakland, California, $261 \mathrm{pp}$.

Jacomb, C. (2008). The chronology of Moncks cave, Canterbury, New Zealand, Records Canterbury Museum 22, 45-56.

Jacomb, C. (2009). Excavations and chronology at the Redcliffs Flat site, Canterbury, New Zealand, Records Canterbury Museum 23, 15-30.

Kaiser, A., J. Beavan, D. Beetham, R. Benites, A. Celentano, D. Collett, J. Cousins, M. Cubrinovski, G. Dellow, P. Denys, et al. (2012). The $M_{\mathrm{w}}$ 6.2 Christchurch earthquake of February 2011: Preliminary report, New Zeal. J. Geol. Geophys. 55, no. 1, 67-90.

Langridge, R., J. Campbell, N. Hill, V. Pere, J. Pope, J. Pettinga, B. Estrada, and K. Berryman (2003). Paleoseismology and slip rate of the Conway segment of the Hope fault at Greenburn Stream, South Island, New Zealand, Ann. Geophys. 46, no. 5, 1119-1139.

Langridge, R. M., P. C. Almond, and R. P. Duncan (2013). Timing of late Holocene paleoearthquakes on the Hurunui segment of the Hope fault: Implications for plate boundary strain release through South Island, New Zealand, Geol. Soc. Am. Bull. 125, 765-775, doi: 10.1130/B30674.1.
Litchfield, N. J., R. J. Van Dissen, R. Sutherland, P. M. Barnes, S. C. Cox, R. Norris, R. J. Beavan, R. M. Langridge, P. Villamor, K. R. Berryman, et al. (2014). A model of active faulting in New Zealand, New Zeal. J. Geol. Geophys. 57, no. 1, 32-56, doi: 10.1080/00288306.2013.854256.

Mackey, B., and M. Quigley (2014). Strong proximal earthquakes revealed by cosmogenic ${ }^{3} \mathrm{He}$ dating of prehistoric rockfalls, Christchurch, New Zealand, Geology 42, doi: 10.1130/G36149.1.

Maurer, B. W., R. A. Green, M. Quigley, and S. Bastin (2015). Development of magnitude-bound relations for paleoliquefaction analyses: New Zealand case study, Eng. Geol. 197, 253-266.

McVerry, G. H., J. X. Zhao, N. A. Abrahamson, and P. G. Somerville (2006). New Zealand acceleration response spectrum attenuation relations for crustal and subduction zone earthquakes, Bull. New Zeal. Soc. Earthq. Eng. 39, no. 1, 1-58.

NZS 1170.5 (2004). Structural Design Actions Part 5: Earthquake ActionsNew Zealand, Standards New Zealand, Wellington, New Zealand, 82 pp.

Obermeier, S. F. (1996). Use of liquefaction-induced features for paleoseismic analysis: An overview of how seismic liquefaction features can be distinguished from other features and how their regional distribution and properties of source sediment can be used to infer the location and strength of Holocene paleo-earthquakes, Eng. Geol. 44, no. 1, 1-76.

Pranter, M. J., A. I. Ellison, R. D. Cole, and P. E. Patterson (2007). Analysis and modeling of intermediate-scale reservoir heterogeneity based on a fluvial point-bar outcrop analog, Williams Fork Formation, Piceance basin, Colorado, AAPG Bull. 91, no. 7, 1025-1051.

Quigley, M. C., S. Bastin, and B. A. Bradley (2013). Recurrent liquefaction in Christchurch, New Zealand, during the Canterbury earthquake sequence, Geology 41, no. 4, 419-422.

Quigley, M. C., R. Van Dissen, N. Litchfield, P. Villamor, B. Duffy, D. Barrell, K. Furlong, T. Stahl, E. Bilderback, and D. Noble (2012). Surface rupture during the $2010 M_{\mathrm{w}} 7.1$ Darfield (Canterbury) earthquake: Implications for fault rupture dynamics and seismic-hazard analysis, Geology 40, no. 1, 55-58.

Reid, C. M., N. K. Thompson, J. R. M. Irvine, and T. E. Laird (2012). Sand volcanoes in the Avon-Heathcote estuary produced by the 2010-2011 Christchurch earthquakes: Implications for geological preservation and expression, New Zeal. J. Geol. Geophys. 55, no. 3, 249-254.

Santucci de Magistris, F., G. Lanzano, G. Forte, and G. Fabbrocino (2013). A database for PGA threshold in liquefaction occurrence, Soil Dynam. Earthq. Eng. 54, 17-19.

Saucier, R. T. (1994). Geomorphology and Quaternary geologic history of the lower Mississippi, U.S. Army Corps of Engineers Waterways Experiment Station, Vols. I/II, 364 pp. and 28 plates.

Seed, H. B., and I. M. Idriss (1971). Simplified procedure for evaluating soil liquefaction potential, J. GED, ASCE 97, no. 9, 1249-1273.

Sibson, R., F. Ghisetti, and J. Ristau (2011). Stress control of an evolving strike-slip fault system during the 2010-2011 Canterbury, New Zealand, earthquake sequence, Seismol. Res. Lett. 82, no. 6, 824-832.

Sisson, R., J. Campbell, J. Pettinga, and D. Miler (2001). Paleoseismicity of the Ashley and Loburn faults, North Canterbury, New Zealand, Project Number, 97/237, Natural Hazards Research Centre, 47 pp.

Smith, G. M., T. R. Davies, M. J. McSaveney, and D. H. Bell (2006). The Acheron rock avalanche, Canterbury, New Zealand: Morphology and dynamics, Landslides 3, no. 1, 62-72.

Stirling, M., G. McVerry, M. Gerstenberger, N. Litchfield, R. Van Dissen, K. R. Berryman, R. M. Langridge, A. Nicol, W. D. Smith, P. Villamor, et al. (2012). National seismic hazard model for New Zealand: 2010 update, Bull. Seismol. Soc. Am. 102, no. 4, 1514-1542.

Sutherland, R., D. Eberhart-Phillips, R. A. Harris, T. A. Stern, R. J. Beavan, S. M. Ellis, S. A. Henrys, S. C. Cox, R. J. Norris, K. R. Berryman, et al. (2007). Do great earthquakes occur on the Alpine fault in central South Island, New Zealand? in A Continental Plate Boundary: Tectonics at South Island, New Zealand, D. A. Okaya, T. A. Stern, and F. J. Davey (Editors), American Geophysical Monograph, Vol. 175, 235-251.

Townsend, D., J. Lee, D. Strong, R. Jongens, Smith-Lyttle, S. Ashraf, B. Rosser, N. Perrin, K. Lyttle, M. Cubrinovski, et al. (2016). Mapping surface liquefaction caused by the September 2010 and February 2011 
Canterbury earthquakes: A digital dataset, New Zeal. J. Geol. Geophys., doi: 10.1080/00288306.2016.1182929 (in press).

Tsuchida, H. (1970). Prediction and countermeasure against the liquefaction in sand deposits, Abstract of the Seminar in the Port and Harbor, Research Institute, Yokohama, Japan, 3-1 p.

Tuttle, M., and N. Barstow (1996). Liquefaction-related ground failure: A case study in the New Madrid seismic zone, central United States, Bull. Seismol. Soc. Am. 86, no. 3, 636-645.

Tuttle, M., T. Law, L. Seeber, and K. Jacob (1990). Liquefaction and ground failure in Ferland, Quebec, triggered by the 1988 Saguenay earthquake, Can. Geotech. J. 27, 580-589.

Tuttle, M. P. (1999). Late Holocene earthquakes and their implications for earthquake potential of the New Madrid seismic zone, central United States, Ph.D. Dissertation, University of Maryland, College Park, 250 pp.

Tuttle, M. P. (2001). The use of liquefaction features in paleoseismology: Lessons learned in the New Madrid seismic zone, central United States, J. Seismol. 5, 361-380.

Tuttle, M. P., and G. M. Atkinson (2010). Localization of large earthquakes in the Charlevoix seismic zone, Quebec, Canada, during the past 10,000 years, Seismol. Res. Lett. 81, no. 1, 140-147.

Tuttle, M. P., and R. Hartleb (2012). Appendix E. Central and Eastern U.S. paleoliquefaction database, uncertainties associated with paleoliquefaction data, and guidance for seismic source characterization, in The Central and Eastern U.S. Seismic Source Characterization for Nuclear Facilities, Technical Report, Electric Power Research Institute, Palo Alto, California, U.S. Department of Energy, and U.S. Nuclear Regulatory Commission, 135 pp. plus database.

Tuttle, M. P., H. Al-Shukri, and H. Mahdi (2006). Very large earthquakes centered southwest of the New Madrid seismic zone 5,000-7,000 years ago, Seismol. Res. Lett. 77, no. 6, 664-678.

Tuttle, M. P., P. Cowie, and L. Wolf (1992). Liquefaction induced by modern earthquakes as a key to paleoseismicity: A case study of the 1988 Saguenay earthquake, A. Weiss (Editor), Proceedings of the Nineteenth International Water Reactor Safety Information Meeting, NUREG/ CP-0119, Vol. 3, 437-462.

Tuttle, M. P., E. S. Schweig, J. D. Sims, R. H. Lafferty, L. W. Wolf, and M. L. Haynes (2002). The earthquake potential of the New Madrid seismic zone, Bull. Seismol. Soc. Am. 92, no. 6, 2080-2089.

Van de Lageweg, W. I., W. M. van Dijk, A. W. Baar, J. Rutten, and M. G. Kleinhans (2014). Bank pull or bar push: What drives scroll-bar formation in meandering rivers? Geology 42, no. 4, 319-322.

Villamor, P., M. Giona-Bucci, P. Almond, M. Tuttle, R. Langridge, K. Clark, W. Ries, M. Vandergoes, P. Barker, F. Martin, et al. (2014). Exploring methods to assess paleoliquefaction in the Canterbury area, GNS Science Consultancy Report Number 2014/183, 142 pp.

Villamor, P., N. Litchfield, D. Barrell, R. Van Dissen, S. Hornblow, M. Quigley, S. Levick, W. Ries, B. Duffy, J. Begg, et al. (2012). Map of the 2010 Greendale fault surface rupture, Canterbury, New Zealand: Application to land use planning, New Zeal. J. Geol. Geophys. 55, no. 3, 223-230.

Wallace, L. M., J. Beavan, R. McCaffrey, K. Berryman, and P. Denys (2007). Balancing the plate motion budget in the South Island, New Zealand using GPS, geological and seismological data, Geophys. J. Int. 168, no. $1,332-352$.

Ward, S. D., M. K. H. Brown, I. R. Brown, and T. J. Larkin (2011). Geological engineering study of liquefaction after the 2010 Darfield earthquake in an area of complex fluvial geology, Proc. of the Ninth Pacific Conference on Earthquake Engineering Building an Earthquake-Resilient Society, Auckland, New Zealand, 14-16 April, 2011, Paper Number 053.

Youd, T. L. (1984). Geologic effects: Liquefaction and associated ground failure, U.S. Geol. Surv. Open-File Rept. 84-760, 210-232.

Youd, T. L., and S. N. Hoose (1977). Liquefaction susceptibility and geologic setting, Proc. of 6th World Conference on Earthquake Engineering, New Delhi, India, Vol. 6, 37-42.

Youd, T. L., I. Idriss, R. Andrus, I. Arango, G. Castro, J. Christian, R. Dobry, W. Finn, L. Harder Jr., M. Hynes, et al. (2001). Liquefaction resistance of soils: Summary report from the 1996 NCEER and 1998 NCEER/ NSF workshops on evaluation of liquefaction resistance of soils, $J$.
Geotech. Geoenviron. Eng. 127, 817-833, doi: 10.1061/(ASCE) 1090-0241(2001)127:10(817).

GNS Science

P.O. Box 30368

Lower Hutt 5040

New Zealand

p.villamor@gns.cri.nz

r.langridge@gns.cri.nz

k.clark@gns.cri.nz

w.ries@gns.cri.nz

m.vandergoes@gns.cri.nz

rocklaboratory@gns.cri.nz

j.howarth@gns.cri.nz

(P.V., R.M.L., K.C., W.R., M.V., P.B., J.H.)

Department of Soil and Physical Sciences

Faculty of Agriculture and Life Sciences

Lincoln University

P.O. Box 85084

Lincoln 7647, Canterbury

New Zealand

Peter.Almond@lincoln.ac.nz

Monica.GionaBucci@lincolnuni.ac.nz

(P.A., M.G.-B.)

M. Tuttle \& Associates

128 Tibbetts Lane

Georgetown, Maine 04548

mptuttle@earthlink.net

(M.P.T.)

Department of Geological Sciences

University of Canterbury

Private Bag 4800

Christchurch 8140, New Zealand

sarah.bastin@pg.canterbury.ac.nz

(S.H.B.)

Department of Soils and Landscapes

Landcare Research

P.O. Box 69040

Lincoln 7640, New Zealand

EgerA@landcareresearch.co.nz

(A.E.)

School of Earth Sciences

The University of Melbourne

Victoria 3010, Australia

mark.quigley@unimelb.edu.au

(M.C.Q.)

Departamento de Biología y Geología

ESCET- Departamental 2

Universidad Rey Juan Carlos

C/ Tulipán s/n

28933 Mostoles

Madrid, Spain

fidel.martin@urjc.e

(F.M.)

Manuscript received 21 August 2015; Published Online 12 July 2016

BSSA Early Edition 